
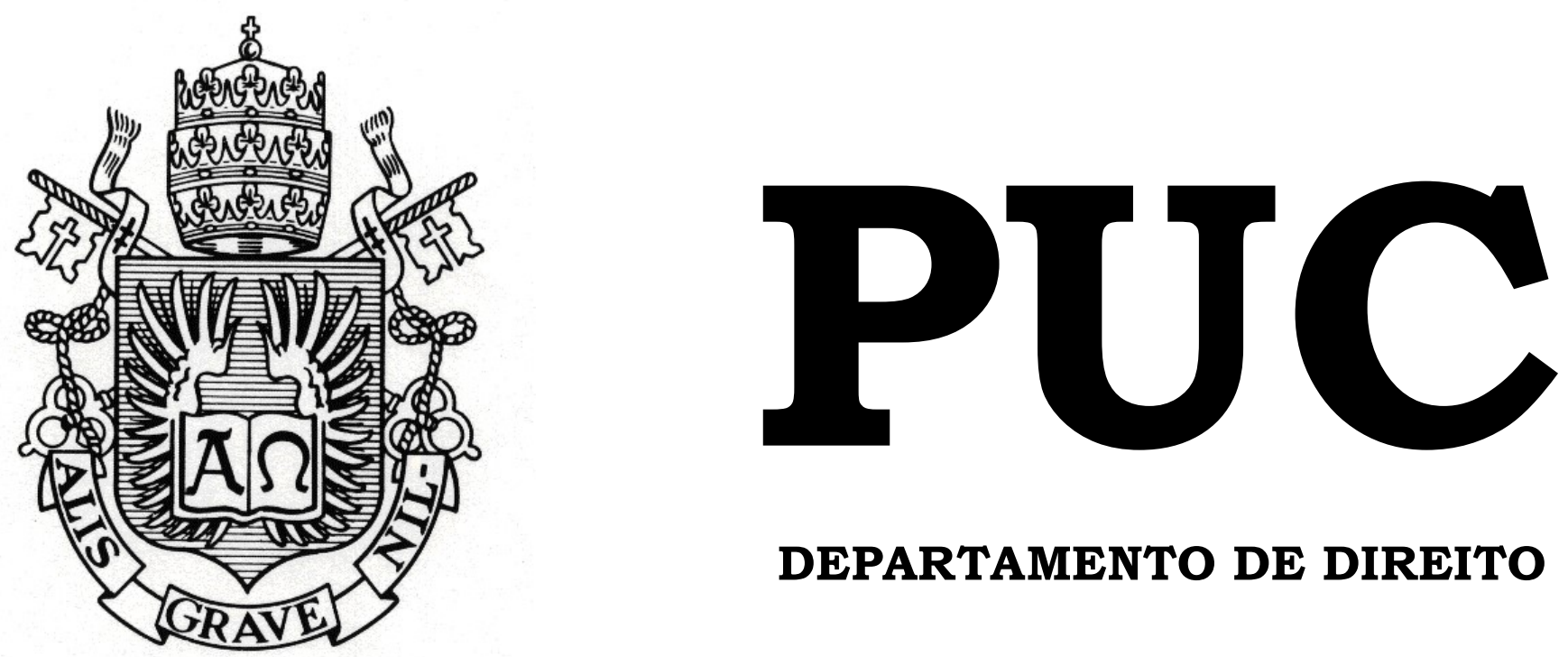

DEPARTAMENTO DE DIREITO

\title{
ANÁLISE CRÍTICA ACERCA DO RECONHECIMENTO COMO PROVA NO PROCESSO PENAL
}

\author{
por \\ FERNANDA BUENTES DOS SANTOS ALMEIDA
}

ORIENTADOR: André Perecmanis

2019.1

PONTIFÍCIA UNIVERSIDADE CATÓLICA DO RIO DE JANEIRO

RUA MARQUÊS DE SÃO VICENTE, 225 - CEP 22453-900

RIO DE JANEIRO - BRASIL 


\title{
ANÁLISE CRÍTICA ACERCA DO RECONHECIMENTO COMO PROVA NO PROCESSO PENAL
}

\author{
por \\ FERNANDA BUENTES DOS SANTOS ALMEIDA
}

Monografia apresentada ao

Departamento de Direito da Pontifícia Universidade Católica do Rio de Janeiro (PUC-Rio) para a obtenção do Título de Bacharel em Direito.

Orientador: André Perecmanis

2019.1 
"A injustiça num lugar qualquer é uma ameaça à justiça em todo lugar".

(Martin Luther King) 


\section{AGRADECIMENTOS}

Agradeço, em primeiro lugar, aos meus pais, Marcia e Paulo César, pelo amor incondicional e pelo apoio e incentivo de sempre. Agradeço por serem os melhores pais do mundo, sem jamais medirem esforços para me verem feliz. Tenho a sorte e o privilégio de ter pais tão atenciosos, amorosos, inteligentes e batalhadores. Sem eles, eu não seria quem sou.

Agradeço ao meu avô, Volmer, que sempre acreditou em mim mais do que eu mesma, que esteve ao meu lado vibrando por cada passo que dei ao longo dessa jornada, comemorando, até mais do que eu, cada conquista. Sem ele, nada disso seria possível.

Agradeço à minha avó, Sonia, que não está mais aqui, mas onde quer que esteja, sei que me acompanhou pelo decorrer do caminho, olhando por mim e me protegendo.

Agradeço aos meus irmãos, Raphael, Anna Carolyna, Ana Carolina e Gabriel, por dividirem comigo o melhor e o pior da vida, somarem as risadas, multiplicarem aminha felicidade e, sobretudo me mostrarem que eu nunca estou sozinha.

Agradeço à minha madrinha, Roberta, que sempre esteve ao meu lado e, para minha felicidade e aprendizado, sempre foi uma mulher engajada e determinada, não hesitando em me corrigir, ensinar e sempre me mostrar o melhor caminho.

Agradeço também ao meu namorado, Patryck, que sempre de forma tão doce e gentil soube ser paciente comigo, me apoiando em todas as minhas escolhas e me motivando a sempre buscar o melhor de mim.

Agradeço ao meu orientador, professor, amigo e chefe, André Perecmanis, responsável pela completa mudança na trajetória que eu vinha seguindo e que se tornou uma grande referência em minha vida, me 
ensinando e mostrando, a cada dia, um pouco mais sobre o garantismo penal e sobre as normas ortográficas.

Agradeço às minhas amigas, Carolina Dias, Carolina Paiva, Carolinne Delgado, Eduarda Nagib, Fernanda Ferman e Yasmin Teixeira e aos meus amigos, Fábio Borda e Felipe Durão, por terem me ensinado o verdadeiro significado de amizade e caminharem comigo, eu sei que vocês são para o resto da vida.

Agradeço também às amigas que a PUC trouxe para a minha vida, Mariana Valência, Ana Caroline Moura e Lorena Araújo. Cada uma delas foi essencial ao longo desses cinco anos.

Agradeço às pessoas que tive a sorte e oportunidade de conhecer no meu estágio junto ao Ministério Público, Dr. Márcio, Silvério, Sílvia, Bárbara, Victor, Carol, Elaine, Louise, Gabi e Mari, por terem sido tão pacientes comigo durante a minha primeira experiência profissional e terem me passado tanto aprendizado de forma tão descontraída e feliz.

Por fim, agradeço aos meus presentes do escritório, Pedro, Marina, Caio, Alice, Glau e Valdi, por tornarem a rotina feliz, por me escutarem e dividirem não só todo conhecimento, mas também a vida comigo. 


\section{RESUMO}

ALMEIDA, Fernanda Buentes dos Santos. Análise crítica acerca do reconhecimento como prova no processo penal. Rio de Janeiro: 2019: 93 p. Monografia de final de curso. Departamento de Direito da Pontifícia Universidade Católica do Rio de Janeiro - PUC-Rio.

O presente trabalho pretende, inicialmente, apresentar noções preliminares acerca da teoria geral da prova no âmbito processual penal, tais como o conceito e a função da prova, o valor probatório do inquérito policial e a diferença entre os atos de prova e de investigação. Analisar-seão os sistemas processuais penais, os princípios relacionados à produção de prova e também a prova como revelação da verdade, a fim de desconstruir esse mito criado. Feitas essas considerações acerca da prova, será abordado o reconhecimento de pessoas e coisas como prova, seu conceito, momento, espécies, natureza jurídica, seus sujeitos e suas fases. Após, tratar-se-á da inobservância à forma ocorrida na realização do ato e, em seguida, de um dos exemplos dessa inobservância comumente utilizado como prova, qual seja o reconhecimento fotográfico. Considerando ainda existência de fatores que influenciam na qualidade e eficácia do ato, tornando-o frágil, falho e pouco confiável, tratar-se-á das falsas memórias, bem como da seletividade penal e do cross-race effect. Por fim, analisar-se-á a ocorrência de condenações injustas com base em reconhecimentos errados, dando o devido destaque à organização "The Innocence Project" e tratando da necessidade de redução de danos desse meio de prova cheio de vícios e erros.

\section{Palavras-chave:}

Processo Penal; Ato de Reconhecimento; Inobservância às formalidades; Fragilidade; Falibilidade; Falsas memórias; Seletividade Penal; Cross-RaceEffect; The Innocence Project; Redução de danos. 


\section{Sumário}



CAPÍTULO 1-TEORIA GERAL DA PROVA ....................................10

1.1. Conceito e função da prova ........................................................... 10

1.2. O valor probatório do inquérito policial ........................................... 12

1.3. Atos de investigação e atos de prova................................................. 13

1.4. Provas repetíveis e não repetíveis................................................... 16







1.6. Princípios processuais penais relativos à produção de prova............ 22

1.6.1. Princípio da presunção de inocência ......................................... 23

1.6.2. Princípio do contraditório e da ampla defesa ..............................26

1.6.3. Princípio do livre convencimento motivado ................................ 29



\section{CAPÍTULO 2 - O RECONHECIMENTO DE PESSOAS E COISAS}



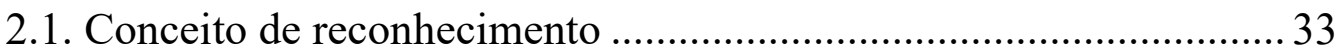

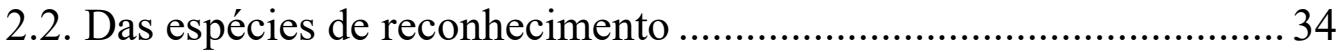

2.2.1. O reconhecimento de pessoas................................................... 34



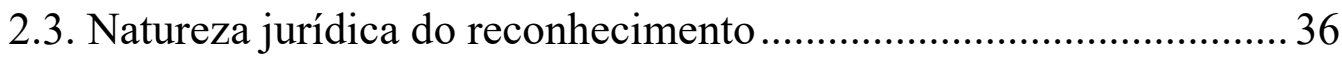

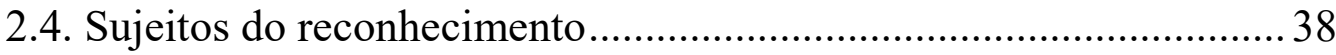



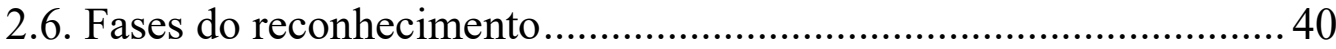

2.6.1. A primeira fase do reconhecimento............................................ 41

2.6.2. A segunda fase do reconhecimento ............................................ 43





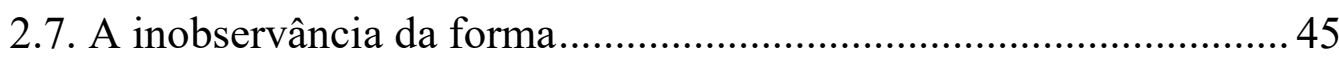

2.8. O reconhecimento fotográfico ......................................................... 49

CAPÍTULO 3 - AS FALSAS MEMÓRIAS E O RECONHECIMENTO 58





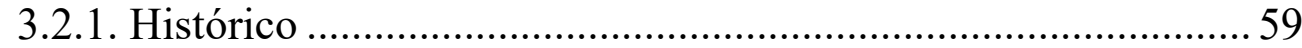

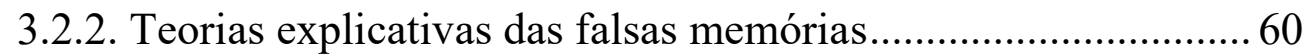

3.2.3. O processo de elaboração das falsas memórias............................ 62 
CAPÍTULO 4 - A FRAGILIDADE E FALIBILIDADE DO RECONHECIMENTO COMO PROVA ...........................................67

4.1. Seletividade Penal .......................................................................... 70

4.2. Cross-race effect ........................................................................ 74

4.3. The innocence project.................................................................. 78

4.4. A necessidade de redução de danos................................................ 83

5. CONCLUSÃ̃

6. REFERÊNCIAS BIBLIOGRÁFICAS ................................................ 90 


\section{INTRODUÇÃO}

O reconhecimento de pessoas e coisas consiste em um meio de prova previsto no ordenamento jurídico, que, se por um lado, é um dos meios mais comuns de prova, permitindo a busca da reconstrução do fato delituoso a partir da identificação de suspeitos e instrumentos que tomaram parte na prática delitiva, por outro, é uma prova eminentemente cognitiva, extremamente passível de erros.

Desse modo, o presente trabalho não busca descredibilizar ou minimizar o ato de reconhecimento, mas sim, apontar os motivos pelos quais essa prova não deve, por si só, ser suficiente para confirmar a autoria delitiva e embasar uma condenação, uma vez que consiste em uma prova altamente suscetível de vícios e erros.

Nesse contexto, dada a importância do formalismo no Processo Penal, uma vez que forma é garantia, tratar-se-á da inobservância às formalidades pelas autoridades que realizam o ato de reconhecimento, bem como se questionará a validade dos atos quando deixam de observar à lei.

Desta forma, o objetivo é analisar os fatores que podem influenciar na confiabilidade do ato, evidenciando, desse modo, a sua fragilidade e falibilidade.

Para tanto, far-se-á, primeiramente, uma análise de algumas noções fundamentais da teoria geral da prova, de modo a se esclarecer alguns conceitos, construindo uma base que permite ao leitor uma melhor compreensão do tema que vem a ser abordado no decorrer do trabalho.

Após, o ato de reconhecimento será detidamente analisado, para que se possa compreender os momentos em que poderá ser realizado, as espécies previstas no nosso ordenamento e, principalmente, as fases do mesmo, cada uma com sua especial razão de ser. 
Em seguida, analisar-se-ão os fatores que podem influenciar no ato de reconhecimento, desde a inobservância à lei, como também o fenômeno das falsas memórias, do cross-race effect, da seletividade penal, dentre outras moduladoras.

Por fim, após destacar a fragilidade e falibilidade que perpassa esse meio de prova, sendo, inclusive, responsável pela condenação de muitos inocentes, serão apresentadas não apenas alterações legislativas a serem realizadas na lei existente, mas também medidas que, se adotadas ao ato tal como previsto, poderão reduzir, expressivamente, os erros provenientes dessa prova. 


\section{CAPÍTULO 1-TEORIA GERAL DA PROVA}

\subsection{Conceito e função da prova}

Para tratar do ato de reconhecimento, insta, inicialmente, analisar algumas noções acerca da prova em geral.

Sendo assim, para conceituar a prova e a sua função, importante ressaltar que o processo penal é um instrumento retrospectivo, de reconstrução aproximada de determinado fato, visando à instrução do juiz.

Nesse sentido, James Goldschmidt afirma que:

O processo penal está destinado a instruir o julgador, a proporcionar o conhecimento do juiz por meio da reconstrução histórica de um fato. Nesse contexto, as provas são os meios através dos quais se fará essa reconstrução do fato passado (crime). ${ }^{1}$

No mesmo sentido, Aury Lopes Jr. afirma que:

O processo penal, inserido na complexidade do ritual do judiciário, busca fazer uma reconstrução (aproximativa) de um fato passado. Através - essencialmente - das provas, o processo pretende criar condições para que o juiz exerça sua atividade recognitiva, a partir da qual se produzirá o convencimento externado na sentença. ${ }^{2}$

A produção de prova consiste então no modo pelo qual se faz a reconstrução do fato criminoso ocorrido, sendo o processo, para Franco Cordero $^{3}$, uma máquina retrospectiva, dirigida a estabelecer se algo ocorreu e quem o realizou, cabendo às partes formular hipóteses e ao juiz acolher a mais provável.

Diante disso, cabe constatar que o vocábulo prova abrange diversos significados, mas, juridicamente:

A prova é a demonstração lógica da realidade, no processo, por meio dos instrumentos legalmente previstos, buscando gerar, no espírito do julgador, a certeza em relação aos fatos alegados e, por consequência, gerando a convicção objetiva para o deslinde da demanda.

Com efeito, o destinatário da prova é o juiz e, acerca da finalidade da mesma, Renato Brasileiro de Lima assevera que:

\footnotetext{
${ }^{1}$ GOLDSCHMIDT, James. DerechoProcesal Civil. Trad. Pietro Castro. Barcelona: Labor, 1936, p. 256. Apud LOPES JR., Aury. Direito Processual Penal. São Paulo: Saraiva, 2015, p. 351.

${ }^{2}$ LOPES JR., Aury. Direito Processual Penal. São Paulo: Saraiva, 2015, p. 352.

${ }^{3}$ CORDERO, Franco. Procedimiento Penal. Tomo I, 2000, p. 11. Apud LOPES JR., Aury. Direito Processual Penal. São Paulo: Saraiva, 2015, p. 353.

${ }^{4}$ NUCCI, Guilherme de Souza. Provas no Processo Penal. Rio de Janeiro: Forense, 2015, p. 15.
} 
A finalidade da prova é a convicção do órgão julgador. Na verdade, por meio da atividade probatória desenvolvida ao longo do processo, objetiva-se a reconstrução dos fatos investigados na fase extraprocessual, buscando a maior coincidência possível com a realidade histórica. Verdade seja dita, jamais será possível se atingir com absoluta precisão a verdade histórica dos fatos em questão. Daí se dizer que a busca é a verdade processual, ou seja, daquela verdade que pode ser atingida através da atividade probatória desenvolvida durante o processo. Essa verdade pode (ou não) corresponder à realidade histórica, sendo certo que é com base nela que o juiz deve proferir sua decisão. ${ }^{5}$

\section{Nas palavras de Aury Lopes Jr.:}

O processo penal tem uma finalidade retrospectiva, em que, através das provas, pretendese criar condições para a atividade recognitiva do juiz acerca de um fato passado, sendo que o saber decorrente do conhecimento desse fato legitimará o poder contido na sentença. ${ }^{6}$

Desse modo, compreendida a importância das provas como meio de reconstrução do fato delituoso, a fim de formar a convicção do julgador, importante se faz a distinção entre atos de prova e atos de investigação, uma vez que, conforme explanado por Ortells Ramos ${ }^{7}$, uma mesma fonte e meio podem gerar atos com natureza e valoração jurídica distintas.

Sendo assim, para fazer uma diferenciação entre os atos de prova e de investigação, importante se faz explicar primeiramente o valor probatório do inquérito policial, uma vez que dele provenientes os atos de investigação.

\footnotetext{
${ }^{5}$ DE LIMA, Renato Brasileiro. Manual de Processo Penal. Salvador: JusPodivm, 2016. p. 578.

${ }^{6}$ LOPES JR., Aury. Direito Processual Penal. São Paulo: Saraiva, 2015, p. 354

${ }^{7}$ Na obra coletiva DerechoJurisdiccional - Processo Penal, cit., v. III, p. 151 e SS. Também no artigo EficaciaProbatoriadelActo de InvestigaciónSumarial. Estudio de los Artículos 730 y 714 de laLECrim. Revista de DerechoProcesallberoamericana, ano 1982, n.2-3, p. 365-427. Apud LOPES JR., Aury. Direito Processual Penal. São Paulo: Saraiva, 2015. p. 155.
} 


\section{2. $O$ valor probatório do inquérito policial}

Inicialmente, importante ressaltar que o inquérito policial acompanhará a denúncia ou queixa-crime, sempre que servir de base a uma ou a outra e assim prevê o artigo 12 do Código de Processo Penal.

Isso porque, após a reunião dos elementos de convicção no inquérito, estar-se-á, possivelmente, diante da justa causa necessária para o ajuizamento da ação penal - seja pelo oferecimento de denúncia ou pela queixa-crime - e, desse modo, o juiz ao analisar o recebimento de uma ou da outra, observará o conjunto dos indícios até ali colhidos, decidindo então pelo processo ou não.

Em outras palavras, esses elementos pré-processuais até então colhidos servem para justificar o recebimento ou o não recebimento da acusação pelo juízo.

Decidindo pelo recebimento, contudo, os elementos colhidos no inquérito, apesar de acompanharem a ação penal, não podem servir como base para uma eventual condenação, sendo necessária a produção de provas na fase processual.

Desse modo, a natureza instrumental da investigação preliminar serve provisionalmente, nas palavras de Aury Lopes Jr, para:

Reconstruir o fato e individualizar a conduta dos possíveis autores, permitindo assim o exercício e a admissão da ação penal. No plano probatório, o valor exaure-se com a admissão da denúncia. Servirá sim para indicar os elementos que permitem produzir a prova em juízo, isto é, para a articulação dos meios de prova. Uma testemunha ouvida no inquérito e que aportou informações úteis será articulada como meio de prova e, com a oitiva em juízo, produz uma prova. Em efeito, o inquérito filtra e aporta as fontes de informação úteis. Sua importância está em dizer quem deve ser ouvido, e não o que foi declarado. A declaração válida é a que se produz em juízo, e não a contida no inquérito. ${ }^{8}$

No mesmo sentido, Nestor Távora e Rosmar Rodrigues Alencar afirmam:

Percebe-se claramente o desejo do legislador, quando com a reforma, define prova como aquilo colhido em instrução judicial, sob o crivo do contraditório e da

\footnotetext{
${ }^{8}$ LOPES JR., Aury. Direito Processual Penal. São Paulo: Saraiva, 2015. p. 155.
} 
ampla defesa, a viabilizar sua valoração como sustentáculo de futura sentença. Os elementos de informação colhidos na investigação preliminar, endemicamente destituídos de contraditório ou ampla defesa, não podem lastrear eventual sentença condenatória. A ressalva foi feita quanto às provas cautelares, não repetíveis e antecipadas. ${ }^{9}$

Dito isso, não obstante a inexistência de previsão legal acerca de uma presunção de veracidade do inquérito policial e de seus elementos, fato é que existe, para boa parte da doutrina e jurisprudência, esse entendimento que considera os atos do inquérito policial válidos até que se prove o contrário.

Nas palavras de Aury Lopes Jr.:

Essa presunção de veracidade gera efeitos contrários à própria natureza e a razão de existir do IP, fulminando seu caráter instrumental e sumário. Também leva a que sejam admitidos no processo atos praticados em um procedimento de natureza administrativa, secreto, não contraditório e sem exercício de defesa. ${ }^{10}$

Assim sendo, considerando-se que os atos realizados em sede policial consistem em elementos de convicção provenientes de atos de investigação que servem para justificar o início ou não da ação penal, podemos então diferenciar esses atos dos atos de prova.

\subsection{Atos de investigação e atos de prova}

Com a finalidade de distinguir os atos de investigação dos de prova, Aury Lopes Jr. os define, sendo os atos de prova aqueles que:

a) estão dirigidos a convencer o juiz da verdade de uma afirmação;

b) estão a serviço do processo e integram o processo penal;

c) dirigem-se a formar um juízo de certeza - tutela de segurança;

d) servem à sentença;

e) exigem estrita observância da publicidade, contradição e imediação;

f) são praticados ante o juiz que julgará o processo. ${ }^{11}$

\footnotetext{
${ }^{9}$ TÁVORA, Nestor e ALENCAR, Rosmar Rodrigues. Curso de Direito Processual Penal. 4. ed. Salvador: Jus Podivm. 2010, p. 100-101.

${ }^{10}$ LOPES JR., Aury. Direito Processual Penal. São Paulo: Saraiva, 2015. p. 154.

${ }^{11}$ Ibidem. p. 155-156.
} 
E assim, o autor prossegue, definindo os atos de investigação, da instrução preliminar, como aqueles que:

a) não se referem a uma afirmação, mas a uma hipótese;

b) estão a serviço da investigação preliminar, isto é, da fase pré-processual e para o cumprimento de seus objetivos;

c) servem para formar um juízo de probabilidade, e não de certeza;

d) não exigem estrita observância da publicidade, contradição e imediação, pois podem ser restringidas;

e) servem para a formação da opinio delicti do acusador;

f) não estão destinadas à sentença, mas a demonstrar a probabilidade do fumus comissi delicti para justificar o processo (recebimento da ação penal) ou o não processo (arquivamento).

g) também servem de fundamento para decisões interlocutórias de imputação (indiciamento) e adoção de medidas cautelares pessoais, reais ou outras restrições de caráter provisional;

h) podem ser praticados pelo Ministério Público ou pela Polícia Judiciária. ${ }^{12}$

A partir da diferenciação que é feita, constata-se que os elementos colhidos no inquérito policial consistem em atos de investigação, tendo, desse modo, um limitado valor probatório, uma vez que produzidos em sede inquisitiva, administrativa e pré-processual.

Diante disso, surge a indagação proposta por Paulo Rangel:

Pode o juiz condenar o réu com base nas provas colhidas durante a elaboração do Inquérito Policial pela Polícia Judiciária, já que possui natureza administrativa de cunho informativo, em que os princípios do contraditório e ampla defesa são, de certa forma, mitigados, fazendo uso do princípio da livre apreciação da prova? Tais provas devem ser absolutamente desvalorizadas devendo ser todas refeitas em juízo sob o crivo dos princípios apontados? ${ }^{13}$

\section{E a explicação vem a seguir:}

A resposta, para nós, a esta indagação, encontra-se na própria natureza jurídica acima mencionada, bem como na essência do princípio da verdade processual sem olvidar o sistema de provas adotado pelo Código: livre convicção. (...) É cediço que o Juiz formará sua convicção pela livre apreciação das provas (cf. Art. 155 do CPP, com redação da Lei 1.690/08), não podendo ser criada nenhuma regra de imposição sobre a apuração e descoberta da verdade, senão a prevista dentro dos limites da prova (cf. Arts. $5^{\circ}$, LVI, da CRFB c/c 155 do CPP). Porém,

\footnotetext{
12 Idem.

${ }^{13}$ RANGEL, Paulo. Direito Processual Penal. Rio de Janeiro: Lumen Juris, 2009. p. 75.
} 
a valoração dos elementos colhidos na fase do inquérito somente poderá ser feita em conjunto com as provas colhidas no curso do processo judicial, pois, sendo o inquérito meramente um procedimento administrativo, de característica inquisitorial, tudo o que nele for apurado deve ser corroborado em juízo. O inquérito, assim, é um suporte probatório sobre o qual repousa a imputação penal feita pelo Ministério Público, mas que deve ser provada em juízo, sob pena de se incidir em uma das hipóteses do art. 386 do CPP. (...) A lei veda, expressamente, que o juiz condene o réu com base apenas nas provas (rectius=informações) colhidas durante a fase do inquérito policial, sem que elas sejam corroboradas no curso do processo judicial, sob o crivo do contraditório, pois a "instrução" policial ocorreu sem a cooperação do indiciado e, portanto, inquisitorialmente. ${ }^{14}$

No mesmo sentido, ao tratar do caráter inquisitivo do inquérito policial e do seu limitado valor probatório ao analisar a impossibilidade de haver uma condenação com base nos atos de investigação, Aury Lopes Jr. bem ressalta que:

É inviável pretender transferir para o inquérito policial a estrutura dialética do processo e suas garantias plenas, da mesma forma que não se pode tolerar uma condenação baseada em um procedimento sem as mínimas garantias. Como equacionar o problema? Valorando adequadamente os atos do inquérito policial e, nas situações excepcionais, em que a repetição em juízo seja impossível, transferindo-se a estrutura dialética do processo à fase pré-processual através do incidente de produção antecipada de provas. ${ }^{15}$

Sendo assim, os elementos coligidos no decorrer do inquérito policial servem para dar início à ação penal ou levar ao arquivamento do procedimento investigatório, mas não para justificar um juízo condenatório.

E mais, esses elementos também podem fundamentar medidas cautelares, sejam estas pessoais, reais ou outras restrições de caráter provisional.

Dito isso, o juiz ao formar a sua convicção e sentenciar, conforme dispõe o art. 155 do Código de Processo Penal ${ }^{16}$, o fará com base nas provas coligidas ao longo da instrução processual, não podendo se referir aos elementos de informação do inquérito policial ao fundamentar, salvo as

\footnotetext{
${ }^{14}$ RANGEL, Paulo. Direito Processual Penal. Rio de Janeiro: Lumen Juris, 2009. p. 75-76.

${ }^{15}$ LOPES JR., Aury. Direito Processual Penal. São Paulo: Saraiva, 2015. p. 156.

${ }^{16}$ Art. 155. O juiz formará sua convicção pela livre apreciação da prova produzida em contraditório judicial, não podendo fundamentar sua decisão exclusivamente nos elementos informativos colhidos na investigação, ressalvadas as provas cautelares, não repetíveis e antecipadas.
} 
provas cautelares, não repetíveis e antecipadas, que serão melhor explanadas a seguir.

\subsection{Provas repetíveis e não repetíveis}

Insta ressaltar, no que tange aos elementos de convicção colhidos na investigação, que estes têm valor probatório limitado, de modo que precisam de repetição em juízo, para só então poderem embasar uma sentença, essas consistem nas provas repetíveis.

Nas palavras de Aury Lopes Jr., as provas repetíveis são muito importantes, uma vez que:

É absolutamente inconcebível que os atos praticados por uma autoridade administrativa, sem a intervenção do órgão jurisdicional, tenham valor probatório na sentença. Não só não foram praticados ante o juiz, senão que simbolizam a inquisição do acusador, pois o contraditório é apenas aparente e muitas vezes absolutamente inexistente. ${ }^{17}$

Diante disso, pode ser dito que:

As provas repetíveis ou renováveis, enquanto inquisitoriais, têm valor meramente informativo - os chamados atos de investigação -, não podendo servir de base ou sequer apoiar subsidiariamente o veredicto condenatório, mas nada impede que sirvam de alicerce ao veredicto absolutório. ${ }^{18}$

Desse modo, para a maior parte da doutrina, as provas renováveis ou repetíveis, como a testemunhal, a acareação e o reconhecimento de pessoa inclusive - acerca da consideração da prova do reconhecimento como prova repetível, mister se faz tecer alguns comentários, já que essa prova deveria ser considerada irrepetível pelas peculiaridades oriundas dela, o que será feito mais adiante -, devem ser repetidas em juízo, para só assim serem passíveis de valoração pelo juízo.

\footnotetext{
${ }^{17}$ LOPES JR., Aury. Direito Processual Penal. São Paulo: Saraiva, 2015. p. 157.

${ }^{18}$ Democratização do Inquérito Policial. In: Estudos de Direito Processual Penal. Porto Alegre, Livraria do Advogado, 1999, v. II, p. 201 e ss. Apud LOPES JR., Aury, Direito Processual Penal. São Paulo: Saraiva, 2015. p. 158.
} 
Isto é, essas provas precisam de reprodução em sede judicial, com a observância de todas as garantias que regem a produção de provas no processo penal e diante do juiz, da acusação e, principalmente, da defesa.

Entretanto, existem elementos colhidos em sede investigatória que não são passiveis de reprodução em juízo, esses consistem em provas não repetíveis e, portanto, exigem a realização da produção antecipada de provas.

Acerca da definição das provas não-repetíveis, Aury Lopes Jr. sustenta que:

As provas não-repetíveis ou não-renováveis são aquelas que, por sua própria natureza, têm que ser realizadas no momento do seu descobrimento, sob pena de perecimento ou impossibilidade de posterior análise. Na grande maioria dos casos, trata-se de provas técnicas que devem ser praticadas no curso do inquérito policial e cuja realização não pode ser deixada para um momento ulterior, já na fase processual. ${ }^{19}$

\section{No mesmo sentido as lições de Ricardo Jacobsen Gloeckner:}

Por irrepetível se tem aquela prova cujo decurso temporal tem o condão de lhe descaracterizar ou diminuir-lhe sensivelmente a qualidade cognitiva. Nesse sentido, é possível afirmar que a prova perece. Perecimento da prova significa a imprestabilidade do elemento de informação para o fim imediato a que se destina: a reconstrução do caso penal. Dessa maneira, uma prova pericial, via de regra quando recai sobre vestígio do crime, deve ser imediatamente produzida, sob pena de as impressões deixadas pelo delito serem apagadas ou corroídas pelo tempo. Da mesma forma uma prova testemunhal que esteja com doença em fase terminal adquiriria o caráter de irrepetibilidade, pois a condição que lhe é específica determina a sua perda para o processo caso não seja de imediato colhida. ${ }^{20}$

Por não serem passíveis de reprodução em juízo, seja pelo perecimento da prova ou pela impossibilidade de posterior análise, Aury Lopes Jr. se posiciona da seguinte forma:

Pela impossibilidade de repetição em iguais condições, tais provas deveriam ser colhidas pelo menos sob a égide da ampla defesa (isto é, na presença fiscalizante da defesa técnica), posto que são provas definitivas e, via de regra, incriminatórias. (...) Nesse sentido, é importante permitir a manifestação da defesa, para postulação de outras provas; solicitar determinado tipo de análise ou

\footnotetext{
${ }^{19}$ LOPES JR., Aury. Direito Processual Penal. São Paulo: Saraiva, 2015. p. 160.

${ }^{20}$ GLOECKNER, Ricardo Jacobsen. Nulidades no Processo Penal. 3. ed. São Paulo: Saraiva, 2017. p. 422.
} 
de meios; bem como formular quesitos aos peritos, cuja resposta seja pertinente para o esclarecimento do fato ou da autoria. ${ }^{21}$

Desse modo, para tornar válida processualmente a prova produzida em sede pré-processual, há o instituto da produção antecipada de provas. Assim, excepcionalmente, diante do risco de perecimento e do prejuízo que significa a perda irreparável dos elementos recolhidos na investigação, o processo penal instrumentaliza uma forma de colher antecipadamente essa prova. $^{22}$

Em outras palavras, Aury Lopes Jr. assevera que:

Aquele elemento que normalmente seria produzido como mero ato de investigação e posteriormente repetido em juízo para ter valor de prova poderá ser realizado uma só vez, na fase pré-processual, e com tais requisitos formais que lhe permitam ter o status de ato de prova. ${ }^{23}$

Dito isso, conclui-se acerca das provas não repetíveis, que estas serão objeto da produção antecipada de provas, de modo que, em tese, demonstrada a fundada probabilidade da inviabilidade da posterior reprodução da prova e a sua relevância para o caso concreto, além de observadas as garantias processuais, serão admitidas.

\subsection{Sistemas processuais penais}

Analisado o conceito e a função da prova e distinguido os atos de prova de atos de investigação, faz-se necessária a análise acerca dos sistemas processuais penais, sendo estes facilmente identificados a partir da posição adotada pelo magistrado na construção do seu convencimento.

Há na doutrina a divisão clássica em três sistemas processuais, quais sejam: o sistema inquisitorial, o sistema acusatório e o sistema misto - com características dos dois sistemas anteriores.

\footnotetext{
${ }^{21}$ LOPES JR., Aury. Direito Processual Penal. São Paulo: Saraiva, 2015. p. 160.

${ }^{22}$ Idem.

${ }^{23}$ Idem.
} 
Entretanto, há que se falar que há quem refute a ideia de um sistema misto, uma vez que ao se partir da ideia de que não existem sistemas puros, é preciso identificar qual é o sistema predominante e quais são as características secundárias do outro sistema ali presentes, em outras palavras, é preciso identificar o princípio informador de cada sistema, para então classificá-lo.

Acerca disso, Aury Lopes Jr. diz:

Ora, afirmar que o sistema é misto é absolutamente insuficiente, é um reducionismo ilusório, até porque não existem mais sistemas puros (são tipos históricos), todos são mistos. A questão é, a partir do reconhecimento de que não existem mais sistemas puros, identificar o princípio informador de cada sistema, para então classificá-lo como inquisitório ou acusatório, pois essa classificação feita a partir do seu núcleo é de extrema relevância. ${ }^{24}$

No mesmo sentido, leciona Jacinto Nelson de Miranda Coutinho, no sentido de que "não há mais sistemas puros, na forma clássica em que foram estruturados. O dito sistema misto, por sua vez, não dispõe de um princípio unificador próprio, configurando-se na conjugação dos outros dois". 25

Dito isso, podemos analisar os sistemas processuais existentes, sendo o inquisitorial, aquele típico de regimes autoritários e o acusatório, característico de regimes democráticos, de modo que, como bem salienta Goldschmidt, "a estrutura do processo penal de uma nação não é mais do que o termômetro dos elementos corporativos ou autoritários de sua constituição". 26

\footnotetext{
${ }^{24}$ LOPES JR., Aury. Direito Processual Penal. 12a Edição. São Paulo: Saraiva, 2015, p. 41.

${ }^{25}$ COUTINHO, Jacinto Nelson de Miranda. "O papel do novo juiz no processo penal". Crítica à Teoria Geral do Direito Processual Penal. Coord. Jacinto Nelson de Miranda Coutinho. Rio de Janeiro: Renovar, 2001, p. 17-18.

${ }^{26}$ GOLDSCHMIDT, James. Princípios Gerais do Processo Penal, 2002, p. 71.
} 


\subsubsection{O sistema inquisitório}

Nesse sistema, a gestão da prova fica nas mãos do julgador (inquisidor), que busca a condenação a qualquer custo ou de qualquer modo. Isso porque, quem vai atrás da prova e valora sua legalidade é a mesma pessoa que ao final irá julgar.

Nesta toada as lições de Aury Lopes Jr.:

Não há nenhum exagero ao se afirmar que o sistema inquisitório busca um determinado resultado (condenação). Basta compreender como funciona sua lógica. Ao atribuir poderes instrutórios a um juiz - em qualquer fase - opera-se o primatodell'ipotesi sui fatti, gerador de quadrimentaliparanoidi. Isso significa que mentalmente (e mesmo inconscientemente) o juiz opera a partir do primado (prevalência) das hipóteses sobre os fatos, porque, como ele pode ir atrás da prova (e vai), decide primeiro (definição da hipótese) e depois vai atrás dos fatos (prova) que justificam a decisão (que na verdade já foi tomada). ${ }^{27}$

No mesmo sentido, Jacinto Coutinho:

Abre-se ao juiz a possibilidade de decidir antes e, depois, sair em busca do material probatório suficiente para confirmar a sua versão, isto é, o sistema legitima a possibilidade da crença no imaginário, ao qual toma como verdadeiro. ${ }^{28}$

Com efeito, ao juiz-inquisidor cabiam as funções de acusar e de julgar, de modo que lhe eram atribuídos plenos poderes para gerir a prova, por meio da investigação, da admissibilidade, produção e valoração da prova.

Dito isso, resta evidente que, nesse sistema, o inquisidor estava "completamente afastado do contraditório, formulava a hipótese acusatória e buscava os substratos probatórios que a comprovasse." 29

Desse modo, trata-se de um sistema sem dialética instrutória, com concentração não só da gestão de provas na mão do juiz, mas também das

\footnotetext{
${ }^{27}$ LOPES JR., Aury. Direito Processual Penal. São Paulo: Saraiva, 2015. p. 356.

${ }^{28}$ COUTINHO, Jacinto Nelson de Miranda. Introdução aos Princípios Gerais do Processo Penal Brasileiro, p. 37.

${ }_{29}$ DI GESU, Cristina. Prova Penal e Falsas Memórias. Porto Alegre: Livraria do Advogado, 2014. p. 31 .
} 
funções de acusar e julgar, sem espaço para o contraditório ser exercido de forma plena, já que evidente a desigualdade de armas e oportunidades para quem investiga/julga e quem se defende.

\subsubsection{O sistema acusatório}

No que tange ao sistema acusatório, neste a gestão da prova fica nas mãos das partes e não do juiz, de modo que há clara divisão entre as funções de investigar, admitir, produzir e valorar as provas.

Com efeito, o sistema acusatório "funda-se no princípio dialético, com ampla regulamentação do conteúdo probatório. O juiz decide conforme o que é trazido aos autos pela acusação e pela defesa". ${ }^{30}$

De acordo com Renato Brasileiro de Lima:

O sistema acusatório caracteriza-se pela presença de partes distintas, contrapondose acusação e defesa em igualdade de condições, e a ambas se sobrepondo um juiz, de maneira equidistante e imparcial. Aqui, há uma separação de funções de acusar, defender e julgar. ${ }^{31}$

Assim, as lições de Cristina di Gesu sintetizam o sistema acusatório, suas garantias e tratamento conferido às partes e, principalmente, à prova, ao asseverar que:

O modelo acusatório destaca-se pela clara distinção entre as atividades de acusar, julgar e defender; pelo fato de o julgador se manter como um terceiro imparcial; pelo tratamento igualitário das partes; pela oralidade e pela publicidade do procedimento (na sua maior parte); pelo contraditório e ampla defesa; pela obrigatoriedade de motivação das decisões judiciais, através da adoção do princípio do livre convencimento motivado, despido de "tarifas" probatórias; pela correlação entre acusação e sentença, pelo duplo grau de jurisdição, pela possibilidade de utilização dos recursos, pela vedação da reformatio in pejus direta e indireta, da regra da liberdade e a prisão como exceção, bem como pela coisa julgada.

Diante do que fora exposto, podemos dizer que apesar de a Constituição da República Federativa do Brasil, consagrada em 1988, ter trazido garantias do sistema acusatório ao tratar da prova no processo penal,

\footnotetext{
${ }^{30}$ DI GESU, Cristina. Prova Penal e Falsas Memórias. Porto Alegre: Livraria do Advogado, 2014. p. 25.

${ }^{31}$ DE LIMA, Renato Brasileiro. Manual de Processo Penal. Salvador: JusPodivm, 2016.p. 39.
} 
fato é que o Código de Processo Penal brasileiro, do ano de 1941, consagrou o modelo inquisitivo, razão pela qual boa parte da doutrina classifica o sistema processual pátrio como neoinquisitorial.

A esse respeito Aury Lopes Jr. nos ensina:

Classificamos de neoinquisitorial, pois é uma inquisição reformada, na medida em que, ao manter a iniciativa probatória nas mãos do juiz, observa o princípio inquisitivo que funda o sistema inquisitório. Claro que não o modelo inquisitório historicamente concebido na sua pureza, mas uma neoinquisição que coexiste com algumas características acessórias mais afins com o sistema acusatório, como a publicidade, oralidade, defesa, contraditório, etc. Não se trata de pósinquisitorial porque isso nos daria uma noção de superação do modelo anterior, o que não é de todo verdade. ${ }^{32}$

Desse modo, podemos dizer que ao atribuir iniciativa probatória ao juiz e dispor sobre a prevenção como causa de fixação de competência, dentre outros exemplos, o sistema consagrado pelo direito processual penal brasileiro é o neoinquisitorial.

\subsection{Princípios processuais penais relativos à produção de prova}

Ao tratar da produção de prova no âmbito do direito processual penal, mister se faz introduzir alguns dos princípios norteadores desta.

Assim, de acordo com as lições de Tourinho:

O processo penal é regido por uma série de princípios e regras que outra coisa não representa senão postulados fundamentais da política processual penal de um Estado. Quanto mais democrático for o regime, o processo penal mais se apresenta como um notável instrumento a serviço da liberdade individual. Sendo o processo penal, como já se disse, uma expressão de cultura, da civilização, e que reflete determinado momento político, evidente que os seus princípios políticos oscilam à medida que os regimes políticos se alternam. ${ }^{33}$

Dessa forma, tem-se que os princípios ou garantias constitucionais funcionam como óbices ao abuso do poder de punir estatal, sendo, na verdade, escudos protetores contra as arbitrariedades do Estado.

\footnotetext{
${ }^{32}$ LOPES JÚNIOR, Aury. Direito Processual Penal. São Paulo: Saraiva, 2015. p. 357.

${ }^{33}$ TOURINHO FILHO, Fernando. Processo Penal. v. I. $35^{\mathrm{a}}$ edição. São Paulo: Saraiva, 2013, p. 58.
} 
Dito isso, importante se faz analisar mais detidamente os princípios considerados basilares de um processo penal democrático e acusatório, quais sejam os princípios da presunção de inocência, do contraditório, da ampla defesa e do livre convencimento motivado.

\subsubsection{Princípio da presunção de inocência ${ }^{34}$}

O princípio da presunção de inocência é expressamente consagrado pela Constituição Federal, em seu art. $5^{\circ}$, LVII $^{35}$ e pelo Pacto de San José da Costa Rica (ou Convenção Americana sobre Direitos Humanos), em seu artigo $8(2)^{36}$, tendo este força de emenda constitucional, tratando-se então de um princípio que embasa o processo penal constitucional democrático.

Por essa razão, é considerado "o princípio reitor do processo penal e, em última análise, podemos verificar a qualidade de um sistema processual através do seu nível de observância (eficácia)". 37

\footnotetext{
${ }^{34}$ Importante ressaltar que o princípio da presunção de inocência é o gênero, do qual são espécies o princípio da presunção de inocência stricto sensu e o da não culpabilidade. Desse modo, entende-se que o princípio da presunção de inocência em sentido estrito se traduz no binômio justa causa, que significa a proteção da dignidade da pessoa humana quanto à sua honra e à imagem, na medida em que impõe limite à persecução criminal, não podendo a autoridade indiciar alguém, o Ministério Público denunciar e o juízo receber a denúncia, sem que tenha uma culpa sumária formada, constituída pela prova da materialidade e indícios de autoria. Assim, quando o juiz vai decidir sobre o recebimento ou não da denúncia, o princípio que se aplica é o da presunção de inocência. Já a incidência do princípio da presunção de não culpabilidade se evidencia no fato de que o Ministério Público tem o dever de provar, enquanto para a defesa se mostra suficiente suscitar dúvida razoável (in dúbio pro reo), o que quer dizer que, enquanto para uma sentença condenatória é necessário que haja suporte em verdade material, para uma absolutória, basta que haja dúvida razoável. Insta ainda esclarecer que por adotarmos a presunção de inocência, não haveria que se falar em qualquer espécie de execução provisória da pena, visto que ainda não há certeza acerca da culpabilidade, contudo, a jurisprudência do STF é, atualmente, pacífica na admissibilidade da mesma. Dito isso, o presente trabalho optou por considerar apenas o nome de princípio da presunção de inocência, uma vez que este consiste no gênero, do qual advêm as espécies explicitadas. (DA SILVA JÚNIOR, Walter Nunes. Princípios da presunção de inocência e da não culpabilidade: distinção, aplicação e alcance. In: Revista Constituição e Garantias de Direitos. Disponível em: $<$ https://periodicos.ufrn.br/constituicaoegarantiadedireitos/article/download/14418/9812/> Acesso em: 25 de maio de 2019).

${ }^{35}$ LVII - ninguém será considerado culpado até o trânsito em julgado da sentença penal condenatória.

${ }^{36}$ Artigo 8. 2. Toda pessoa acusada de delito tem direito a que se presuma sua inocência enquanto não se comprove legalmente sua culpa.

${ }^{37}$ LOPES JR., Aury. Direito Processual Penal. São Paulo: Saraiva, 2015. p. 92.
} 
Nas lições de Luigi Ferrajoli:

A presunção de inocência pode ser conceituada como uma opção garantista a favor da tutela da imunidade dos inocentes, inclusive, ao preço da impunidade de algum culpado, traduzindo-se em um princípio fundamental de civilidade. ${ }^{38}$

Acerca desse princípio, Jaime Vegas Torres aponta as suas três principais manifestações:

a) É um princípio fundante, em torno do qual é constituído todo o processo penal liberal, estabelecendo essencialmente garantias para o imputado frente à atuação punitiva estatal;

b) É um postulado que está diretamente relacionado ao tratamento do imputado durante o processo penal, segundo o qual haveria de partir-se da ideia de que ele é inocente e, portanto, deve reduzir-se ao máximo as medidas que restrinjam seus direitos durante o processo (incluindo-se, é claro, a fase pré-processual);

c) Finalmente, a presunção de inocência é uma regra diretamente referida ao juízo do fato que a sentença penal faz. É sua incidência no âmbito probatório, vinculando à exigência de que a prova completa da culpabilidade do fato é uma carga da acusação, impondo-se a absolvição do imputado se a culpabilidade não ficar suficientemente demonstrada. ${ }^{39}$

No que tange ao princípio da presunção de inocência como regra de tratamento durante o processo penal, Tourinho afirma:

Enquanto não definitivamente condenado, presume-se o réu inocente. Sendo este presumidamente inocente, sua prisão, antes do trânsito em julgado da sentença condenatória, somente poderá ser admitida a título de natureza cautelar. ${ }^{40}$

Desse modo, sabe-se que, por força do princípio da presunção de inocência, não é admitida a prisão sem que haja o preenchimento dos requisitos previstos nos artigos 312 e 313 do CPP e uma decisão nesse sentido devidamente fundamentada, conforme postula o art. 93, IX, CF.

Assim sendo, a liberdade é a regra e a prisão cautelar exceção. Contudo, tratando-se da prisão enquanto pena, decorrente de uma decisão condenatória, esta, em tese, só deveria ocorrer após o trânsito em julgado.

\footnotetext{
${ }^{38}$ FERRAJOLI, Luigi. Derecho y Razón: Teoria del Garantismo Penal. Madrid: Trotta, 1997. P. 549 apud DI GESU, Cristina. Prova Penal e Falsas Memórias. Porto Alegre: Livraria do Advogado, 2014.p. 64.

39 VEGAS TORRES, Jaime. Presunción de Inocencia y PruebaenelProceso Penal, p. 35 apudLOPES JR., Aury. Direito Processual Penal. São Paulo: Saraiva, 2015, p. 93.

${ }^{40}$ TOURINHO FILHO, Fernando. Processo Penal. v. I. $35^{\mathrm{a}}$ edição. São Paulo: Saraiva, 2013. p. 65.
} 
Ocorre que, em julgamento realizado em 2016 - HC $126.292^{41}$-, por maioria de votos, surpreendentemente, o plenário do Supremo Tribunal Federal concluiu haver a possibilidade de se executar provisoriamente a pena após acórdão condenatório proferido em segunda instância, ainda que pendentes recursos aos tribunais superiores e ausentes os requisitos que ensejariam a prisão antes do trânsito em julgado.

Diante dessa mudança de entendimento, passou-se a ser admitida a prisão provisória antes do trânsito em julgado, sem, contudo, se tratar de prisão cautelar, mas sim de execução provisória da pena.

A respeito dessa mudança de posicionamento da Suprema Corte, Renato Brasileiro muito bem se posiciona divergindo:

Com a devida vênia à maioria dos Ministros do STF que admitiram a execução provisória da pena, parece-nos que a decisão proferida no julgamento do HC 126.292 contraria flagrantemente a Constituição Federal, que assegura a presunção de inocência (ou de não culpabilidade) até o trânsito em julgado de sentença condenatória (art. 5 $5^{\circ}, \mathrm{LVII}$ ), assim como o art. 283 do CPP, que só admite, no curso das investigações ou do processo - é dizer, antes do trânsito em julgado de sentença condenatória -, a decretação da prisão temporária ou preventiva por ordem escrita e fundamentada da autoridade policial. ${ }^{42}$

No que tange à matéria probatória, importante salientar que esse princípio faz com que o ônus da prova, no processo penal, recaia integralmente sobre o órgão acusador.

Desse modo, sabendo que, no processo penal, o ônus de provar a autoria e materialidade delitiva é exclusivamente do titular da ação penal, o princípio da presunção de inocência garante que não sendo reunidas provas suficientes pela acusação, o magistrado deve absolver o réu.

\footnotetext{
${ }^{41}$ EMENTA: CONSTITUCIONAL. HABEAS CORPUS. PRINCÍPIO CONSTITUCIONAL DA PRESUNÇÃO DE INOCÊNCIA (CF, ART. $5^{\circ}$, LVII). SENTENÇA PENAL CONDENATÓRIA CONFIRMADA POR TRIBUNAL DE SEGUNDO GRAU DE JURISDIÇÃO. EXECUÇÃO PROVISÓRIA. POSSIBILIDADE. 1. A execução provisória de acórdão penal condenatória proferido em grau de apelação, ainda que sujeito a recurso especial ou extraordinário, não compromete o princípio constitucional da presunção de inocência afirmado pelo art. $5^{\circ}$, inciso LVII da Constituição Federal. 2. Habeas corpus denegado. (HC 126.292/SP, Rel. Min. Dias Toffoli, $2^{\text {a }}$ Turma, j. 17/02/2016, Dje 22/02/2016)

${ }^{42}$ DE LIMA, Renato Brasileiro. Material Suplementar $1^{\circ}$ semestre 2016. Salvador: JusPodivm, 2016. p. 10
} 
Diante disso, podemos afirmar que o princípio aqui em comento pode ser analisado sob duas óticas: a regra de tratamento, no que tange à prisão e como regra processual, no que concerne à produção probatória.

Nas palavras de Di Gesu:

Processualmente falando, o princípio da presunção de inocência possui um dúplice significado, tendo implicações diretas no âmbito da prisão e da prova. Em síntese, no que concerne à prisão, determina ser a utilização de medidas restritivas da liberdade pessoal reservada aos casos excepcionais, pois a liberdade é a regra e a prisão a exceção. Quanto à matéria probatória, a presunção de inocência é tida como regra processual, no sentido de o acusado não ser obrigado a fornecer prova de sua inocência, pois esta é presumida e, em caso de dúvida, impera a absolvição. ${ }^{43}$

Sendo assim, pode ser dito que o princípio da presunção de inocência é um dos pilares do Estado Democrático de Direito e assim, não sendo reunidas provas suficientes contra o acusado, este deverá ser absolvido, pois presumida a sua inocência.

Desse modo, importante se faz analisar o direito do acusado de contraditar a prova produzida pela acusação, de produzir as provas que almejar e ainda, diminuir os riscos de uma sentença condenatória, por meio do exercício da ampla defesa, o que se passa a expor.

\subsubsection{Princípio do contraditório e da ampla defesa}

Os princípios do contraditório e da ampla defesa consistem em garantias constitucionais, previstas no artigo $5^{\circ}$, inciso $\mathrm{LV}^{44}$, da Constituição Federal, sendo importante esclarecer que embora sejam princípios intimamente relacionados, de difícil constatação de diferenciação prática, na teoria, há que se falar em algumas diferenças relevantes.

A esse respeito, Cristina di Gesu:

\footnotetext{
${ }^{43}$ DI GESU, Cristina. Op. cit. p. 64-65.

${ }^{44} \mathrm{LV}$ - aos litigantes, em processo judicial ou administrativo, e aos acusados em geral são assegurados o contraditório e ampla defesa, com os meios e recursos a ela inerentes.
} 
A distinção entre contraditório e ampla defesa assume especial relevância no campo das nulidades, na medida em que pode haver violação de uma das garantias sem que a outra seja, necessariamente, transgredida. Nessa senda, viável o cerceamento de defesa sem violação do contraditório; entretanto, a recíproca não é verdadeira, pois não é possível, em tese, que a parte não comunicada, isto é, não informada acerca de uma manifestação processual possa se defender. ${ }^{45}$

O contraditório então, para Aury Lopes, deve ser encarado como um método de confrontação da prova e comprovação da verdade, de modo que contradizer a suposta verdade afirmada pela acusação é ato imprescindível para um mínimo de configuração acusatória do processo. Desse modo, o contraditório conduz ao direito de audiência e às alegações mútuas das partes, em observância à estrutura dialética do processo. ${ }^{46}$

Nesse sentido, Aury Lopes ao tratar do princípio do contraditório em matéria probatória salienta que o princípio deve ser rigorosamente observado nos quatro momentos da prova, são eles:

$1^{\circ}$ Postulação (denúncia ou resposta escrita): contraditório está na possibilidade de também postular a prova, em igualdade de oportunidades e condições; $2^{\circ}$ Admissão (pelo juiz): contraditório e direito de defesa concretizam-se na possibilidade de impugnar a decisão que admite a prova; $3^{\circ}$ Produção (instrução): o contraditório manifesta-se na possibilidade de as partes participarem e assistirem a produção da prova; $4^{\circ}$ Valoração (na sentença): o contraditório manifesta-se através do controle da racionalidade da decisão (externada pela fundamentação) que conduz à possibilidade de impugnação pela via recursal. Sublinhe-se a imprescindibilidade do contraditório, que deve permear todos os atos e momentos da prova. ${ }^{47}$

Importante considerar, no entanto, que o contraditório se divide em duas outras garantias, quais sejam o direito à informação e à participação.

Acerca do direito à informação, este decorre do fato de que não se pode cogitar da existência de um processo penal eficaz e justo sem que a parte adversa seja cientificada da existência da demanda ou dos argumentos

\footnotetext{
${ }^{45}$ DI GESU, Cristina. Op. cit. p. 66.

${ }^{46}$ LOPES JR., Aury. Direito Processual Penal. São Paulo: Saraiva, 2015. p. 94.

${ }^{47}$ LOPES JR., Aury. Direito Processual e a sua Conformidade Constitucional. v. I. $8^{\mathrm{a}}$ ed. Porto Alegre: Lumen Juris, 2011, p. 533.
} 
da parte contrária. Por esse motivo, os meios de comunicação dos atos processuais - citação, intimação e notificação - são muito importantes. ${ }^{48}$

Já no que tange ao direito à participação, este é compreendido como a possibilidade de a parte oferecer reação, manifestação ou contrariedade à pretensão da parte contrária. Sendo importante ressaltar que não basta que essa reação seja possibilitada - reação possível -, é preciso que essa seja de fato realizada. ${ }^{49}$

Esclarecido o princípio do contraditório, há ainda que se tratar do princípio da ampla defesa, que possui duas faces: defesa técnica e defesa pessoal ou autodefesa.

Com relação à defesa técnica, essa encontra previsão no artigo 261 do Código de Processo Penal que dispõe que "nenhum acusado, ainda que ausente ou foragido, será processado ou julgado sem defensor”, sendo então esta defesa indisponível e, de acordo com Cristina di Gesu:

Isso quer dizer que o sujeito passivo deve, necessariamente, ser acompanhado de advogado, ou seja, de pessoa dotada de conhecimentos teóricos de direito, devido à sua hipossuficiência, a fim de que se possa garantir a paridade de armas e o equilíbrio processual em relação ao Ministério Público. ${ }^{50}$

Diferentemente da defesa técnica, a defesa pessoal é renunciável, de modo que é assegurado ao acusado o direito de depor, apresentar suas versões dos fatos e expressar os motivos pelos quais deve ser absolvido das imputações que lhe são feitas, bem como o direito de permanecer em silêncio ${ }^{51}$, sem que isso possa ser interpretado em seu desfavor.

\footnotetext{
${ }^{48}$ DE LIMA, Renato Brasileiro. Manual de Processo Penal. Salvador: JusPodivm, 2016, p.50.

${ }^{49}$ Idem.

${ }^{50}$ DI GESU, Cristina. Op. cit. p. 70

${ }^{51}$ O direito ao silêncio encontra previsão no artigo 186 do Código de Processo Penal: "Depois de devidamente qualificado e cientificado do inteiro teor da acusação, o acusado será informado pelo juiz, antes de iniciar o interrogatório, do seu direito de permanecer calado e de não responder perguntas que lhe forem formuladas. "Além disso, insta esclarecer que esse direito decorre da garantia que é assegurada ao acusado de não produzir prova contra si mesmo (nemotenetur se detegere), podendo se eximir da prática de qualquer ato que possa ser prejudicial à sua defesa.
} 
Por fim, há que se falar que a ampla defesa dever ser efetiva, não bastando a atuação de uma defesa meramente formal, nesse sentido, Nereu Giacomolli:

A ampla defesa deve ser efetiva, não garantindo seu exercício a simples constituição ou nomeação de um defensor. A defesa deve produzir uma antítese firme e consistente à tese acusatória, utilizando-se dos meios disponíveis para rebatê-la. Ademais, ainda enfatiza que meras alegações, abstratas e genéricas, sem exame do conteúdo do processo, embora configurem a defesa sob o ponto de vista formal, não implicam o reconhecimento desta sob o ponto de vista substancial. ${ }^{52}$

\subsubsection{Princípio do livre convencimento motivado}

O último princípio que merece destaque é o do livre convencimento motivado e este encontra respaldo no artigo 93, inciso IX, da Constituição Federal $^{53}$, e no artigo 155, do Código de Processo Penal.

\section{Acerca de sua definição, Renato Brasileiro:}

De acordo com o sistema do livre convencimento motivado (persuasão racional ou livre apreciação judicial da prova), o magistrado tem ampla liberdade na valoração das provas constantes dos autos, as quais têm, legal e abstratamente, o mesmo valor, porém se vê obrigado a fundamentar suas decisões. ${ }^{54}$

\section{No mesmo sentido, Guilherme Nucci:}

Liberdade possui o juiz para examinar e atribuir valores às provas, mas está atrelado a elas no tocante à construção do seu convencimento em relação ao deslinde da causa. E, justamente por isso, espera-se do magistrado a indispensável fundamentação de sua decisão, expondo as razões pelas quais chegou ao veredicto absolutório ou condenatório, em regra. ${ }^{55}$

Assim sendo, conclui-se que não há que se falar em hierarquia entre as provas no processo penal, contando o juiz com liberdade e independência para prolação de suas sentenças, devendo, somente, fundamentar suas decisões.

\footnotetext{
${ }^{52}$ GIACOMOLLI, Nereu. Juizados Especiais Criminais. Lei 9.099/95. $2^{\mathrm{a}}$ ed., 2002, p. 48-49.

${ }^{53}$ Art. 93, IX, da CRFB: todos os julgamentos dos órgãos do Poder Judiciário serão públicos, e fundamentadas todas as decisões, sob pena de nulidade, podendo a lei limitar a presença, em determinados atos, às próprias partes e a seus advogados, ou somente a estes, em casos nos quais a preservação do direito à intimidade do interessado no sigilo não prejudique o interesse público à informação;(Redação dada pela Emenda Constitucional no 45, de 2004)

${ }^{54}$ DE LIMA, Renato Brasileiro. Manual de Processo Penal. Salvador: JusPodivm, 2016. p. 606.

${ }^{55}$ NUCCI, Guilherme de Souza. Provas no Processo Penal. Rio de Janeiro: Forense, 2015, p. 19.
} 


\subsection{Prova como revelação da verdade}

Antes de finalizar a análise da teoria da prova no processo penal, podemos tratar da ambição inquisitorial da prova como revelação da verdade, ou o mito da verdade real.

Como já explanado, a atividade de provar está intimamente ligada à busca da verdade, uma vez que a colheita de provas no processo penal visa à reconstrução do fato delituoso.

Acerca disso, Aury Lopes Jr. afirma:

Historicamente, está demonstrado empiricamente que o processo penal, sempre que buscou uma "verdade mais material e consistente" e com menos limites na atividade de busca, produziu uma "verdade" de menor qualidade e com pior trato para o imputado. Esse processo, que não conhecia a ideia de limites - admitindo inclusive a tortura -, levou mais gente a confessar não só delitos não cometidos, mas também alguns impossíveis de serem realizados. ${ }^{56}$

Ainda sobre essa busca da verdade, o autor prossegue:

O mito da verdade real está intimamente relacionado com a estrutura do sistema inquisitório; como "interesse público" (cláusula geral que serviu de argumento para a maioria das atrocidades); com sistemas políticos autoritários; com busca de uma "verdade" a qualquer custo (chegando a legitimar a tortura em determinados momentos históricos); e com a figura do juiz-autor (inquisidor). ${ }^{57}$

Assim sendo, sabe-se que a verdade real buscada através da instrução probatória é proveniente do sistema inquisitorial no qual estavam concentradas nas mãos do juiz a gestão e valoração das provas, sendo ele produtor e destinatário das mesmas.

Ocorre que, isso é incompatível com a nossa Constituição Federal e com a consagração feita por esta de um sistema acusatório. Nesse sentido Aury Lopes Jr. e Cristina Di Gesu afirmam:

É ingenuidade seguir falando em "verdade processual" ou, mais grave ainda, falar-se na (absurda) verdade real, cuja única "realidade" é fundar um sistema inquisitório. No processo acusatório, a "verdade" dos fatos não é elemento fundamente do sistema. O poder do julgador não se legitima pela verdade, tendo

\footnotetext{
${ }^{56}$ LOPES JR., Aury. Introdução Crítica ao Processo Penal - Fundamentos da Instrumentalidade Garantista, 3ª ed., 2005, p. 267.

${ }^{57}$ Idem.
} 
em vista que o poder contido na sentença é válido pela versão mais convincente sobre o fato, seja a da acusação ou da defesa. O que importa é o convencimento do julgado. ${ }^{58}$

Ainda nesse discurso de busca da verdade real, importante, no entanto, atentar que Giacomolli alertou para a busca da "incidência do ius puniendi a todo custo, a qualquer preço, concepção da necessidade inafastável da condenação de alguém, da culpabilidade objetiva, ou seja, pelo cometimento do fato, independentemente da verificação ou não de seus elementos". 59

Diante disso, construiu-se, alternativamente, a ideia de busca pela verdade judicial ou, de acordo com Ada Pellegrini Grinover ${ }^{60}$ e outros autores, deve haver, antes de tudo, uma "verdade processualmente válida".

\section{Nesse sentido, Eugênio Pacelli:}

O processo penal deve construir uma verdade judicial, sobre a qual, uma vez passada em julgado a decisão final, incidirão os efeitos da coisa julgada, com todas as suas consequências, legais e constitucionais. O processo, portanto, produzirá uma certeza do tipo jurídica, que pode ou não corresponder à verdade da realidade histórica (da qual, aliás, em regra, jamais se saberá), mas cuja pretensão é a de estabilização das situações eventualmente conflituosa que vêm a ser o objeto da jurisdição penal. ${ }^{61}$

\section{Nessa linha também as lições de Ferrajoli:}

Esta verdade não pretende ser a verdade; não é obtida mediante indagações inquisitivas alheias ao objeto pessoal; está condicionada em si mesma pelo respeito aos procedimentos e às garantias de defesa. ${ }^{62}$

\footnotetext{
58 LOPES JUNIOR, Aury; GESU, Carla Cristina Di. Falsas memórias e prova testemunhal no processo penal: em busca da redução de danos. In: Revista de Estudos Criminais, Ano VII, n. 25. Sapucaia do Sul: 2007, p. 59-69.

59 GIACOMOLLI, Nereu. José. Atividade do Juiz Criminal Frente à Constituição: deveres $e$ limites em face do princípio acusatório. Sistema Penal e Violência. Ruth Maria Chittó Gauer (coord.), 2006, p. 226.

${ }^{60}$ GRINOVER, Ada Pellegrini; GOMES FILHO, Antonio Magalhães; FERNANDES, Antonio Scarance. As nulidades no processo penal. 7. ed. São Paulo: RT, 2001.

${ }^{61}$ PACELLI, Eugênio; FISCHER, Douglas. Comentários ao Código de Processo Penal e sua jurisprudência, $4^{\mathrm{a}}$ ed. revista e atualizada, São Paulo, Atlas, 2012, p. 326.

${ }^{62}$ FERRAJOLI, Luigi. Direito e razão. 2. ed. rev. e ampl. Tradução de Ana Paula Zomer, Fauzi Hassan Choukr, Juarez Tavares e Luiz Flávio Gomes. São Paulo: Ed. RT, 2006. p.48.
} 
Desse modo, resta claro que não há que se falar na verdade real, mas sim na "verdade" que há de surgir aos olhos do juiz a partir da produção de provas.

Em outras palavras, o importante é o convencimento do juiz na avaliação das provas produzidas, uma vez que este não precisa encontrar a incontestável "verdade real" para legitimar sua decisão. Acerca disso, Thompson indaga:

O que é dúvida, o que é certeza plena? Há dúvida quando há uma possibilidade em dez de que a acusação não seja verdadeira? Ou quando essa possibilidade é de uma para cem? Ou para mil? Em qualquer processo haverá sempre uma possibilidade, ainda que mínima, de que a acusação não seja veraz. Minha experiência, a compulsar milhares de feitos, ensinou-me isso. Por consequência, a famosa "certeza legal" jamais, ou rarissimamente, estará livre de alguma eiva de incerteza. Na verdade, as decisões são fruto da opinião do julgador, uma vez que o material sobre o qual trabalha não lhe permite atingir um estágio de certeza ou, pelo menos, de certeza intrínseca - mas tão apenas de crença. ${ }^{63}$

Assim, conclui-se que a verdade real e absoluta é inalcançável no processo penal, pois além de não serem admitidas as provas empregadas no sistema inquisitorial - como, por exemplo, a tortura -, a prova produzida pela mente humana apresenta uma peculiaridade, qual seja a impossibilidade de reconstrução do fato ou da imagem tal como aconteceu.

Dito isso, será melhor abordado no decorrer deste trabalho que as provas apresentadas pelas vítimas e testemunhas não podem ser compreendidas como verdades reais, uma vez que consistem em uma atividade retrospectiva ou recognitiva "que envolve uma série de fatores complexos, dependendo, na grande maioria das vezes, da memória, da emoção, da formação de falsas lembranças, entre outros fatores". ${ }^{64}$

\footnotetext{
${ }^{63}$ THOMPSON, Augusto. Quem são os criminosos? 2.ed. Rio de Janeiro: Editora Lumen juris, 2007, p. $89-90$

${ }^{64}$ DI GESU, Cristina. Op. cit. p. 88.
} 


\section{CAPÍTULO 2 - O RECONHECIMENTO DE PESSOAS E COISAS COMO PROVA}

\subsection{Conceito de reconhecimento}

De acordo com o dicionário Aurélio, reconhecer consiste em "conhecer novamente (por certas particularidades) que uma pessoa ou coisa é a mesma que noutro tempo nos foi conhecida; achar que é o mesmo". 65

Assim, pode ser dito que o reconhecimento é "um ato através do qual alguém é levado a analisar alguma pessoa ou coisa e, recordando do que havia percebido em um determinado contexto, compara as duas experiências". ${ }^{66}$

Em outras palavras, "quando coincide a recordação empírica com essa nova experiência levada a cabo em audiência ou no inquérito policial, ocorre o reconhecer". ${ }^{67}$

No mesmo sentido, Tourinho define o reconhecimento como:

Ato por que se faz a verificação e confirmação da identidade de pessoa ou coisa. No reconhecimento há a fusão de uma percepção presente com outra pretérita. A pessoa que procede ao reconhecimento faz uma evocação à reminiscência e procura ver a semelhança entre aquela figura guardada na memória e aquela que lhe é apresentada. ${ }^{68}$

Assim também, Gustavo Henrique Righi Ivahy Badaró afirma que o reconhecimento consiste em:

Um meio de prova formal, pelo qual alguém é chamado para descrever uma pessoa ou coisa por ele vista no passado, para verificar e confirmar a sua identidade perante outras pessoas ou coisas semelhantes às descritas. ${ }^{69}$

\footnotetext{
${ }^{65}$ FERREIRA, Aurélio Buarque de Holanda. Dicionário do Aurélio Online. Disponível em: $<\mathrm{https}$ ://dicionariodoaurelio.com/reconhecer>. Acesso em: 11/05/2019.

${ }^{66}$ CORDERO, Franco. Procedimiento Penal. Tomo I, 2000, p. 106. Apud LOPES JR., Aury. Direito Processual Penal. São Paulo: Saraiva, 2015, p. 495.

${ }^{67}$ LOPES JR., Aury. Direito Processual Penal. São Paulo: Saraiva, 2015. p. 495.

${ }^{68}$ TOURINHO FILHO, Fernando da Costa. Código de Processo Penal Comentado. 13. ed. rev. e atual. São Paulo: Saraiva, 2010. p. 670.

${ }^{69}$ BADARÓ, Gustavo Henrique Righilvahy. Direito Processual Penal. São Paulo: Campus Jurídico, 2008, Tomo I, p. 257.
} 
Desse modo, o reconhecimento é um meio de prova que consiste em um juízo de identidade estabelecido por um processo comparativo do que se vê com as lembranças do que se viu, com a finalidade de obter a identificação de uma pessoa ou coisa que tenha estado envolvida em um ato criminoso.

\subsection{Das espécies de reconhecimento}

Há duas espécies de reconhecimento, o de pessoas e o de coisas. As variações, contudo, podem ocorrer dentro dessas categorias.

Importante notar que, em geral, as legislações tratam apenas do reconhecimento de pessoas e de coisas na modalidade visual e presencial. Sendo raros dispositivos que disponham acerca do reconhecimento de pessoas não presencial, qual seja o fotográfico, ou ainda que dependam de outros sentidos, como o auditivo, por exemplo.

Assim, para Aury Lopes Jr., parte-se da premissa de que:

É reconhecível tudo o que podemos perceber, ou seja, só é possível de ser reconhecido o que pode ser conhecido pelos sentidos. Nessa linha, o conhecimento por excelência é o visual, assim previsto no CPP. Contudo, silencia o Código no que se refere ao reconhecimento que dependa de outros sentidos, como o acústico, olfativo ou táctil. ${ }^{70}$

\subsubsection{O reconhecimento de pessoas}

O reconhecimento de pessoas como prova no processo penal é o ato que visa obter de um indivíduo - seja ele vítima, testemunha ou coautor de um ato criminoso - a identificação de uma outra pessoa suspeita de ter praticado aquele ato delitivo.

De acordo com Eduardo Jauchen, no reconhecimento de pessoas, o indivíduo ao reconhecer é convidado a "expressar se, da confrontação com

\footnotetext{
${ }^{70}$ LOPES JR., Aury. LOPES JR., Aury. Direito Processual Penal. São Paulo: Saraiva, 2015. p. 495.
} 
as pessoas que lhe exibe, pode afirmar ou negar a identidade de alguma delas". ${ }^{71}$

Importante reiterar que, conforme a previsão legal, o reconhecimento pessoal é visual e presencial, devendo a pessoa investigada ser colocada ao lado de pessoas com características semelhantes a ela e compatíveis com a descrição daquela que vai realizar o ato de reconhecimento.

Entretanto, há que se falar que na ausência da pessoa a ser reconhecida, o reconhecimento acaba sendo realizado de forma visual, mas não presencial, por meio do uso de fotografias, o que é amplamente refutado por grande parte da doutrina, uma vez que não há previsão legal para tal.

\subsubsection{O reconhecimento de coisas}

Já o reconhecimento de coisas como prova no processo penal é o ato que visa à obtenção do reconhecimento - pela vítima, testemunha ou coautor do ato criminoso - de determinada coisa utilizada na prática delitiva.

Em outras palavras, são suscetíveis do reconhecimento objetos que podem ter sido utilizados na empreitada criminosa, como, por exemplo, armas, facas e outros instrumentos.

O procedimento do reconhecimento de coisas é previsto no ordenamento jurídico, sendo um meio de prova típico, cuja realização é visual e presencial.

\footnotetext{
${ }^{71}$ JAUCHEN, Eduardo M. Tratado de lapruebaen matéria penal. Santa Fé: Rubinzal-Culzoni Editores, 2009, p. 462-463. Apud LOPES, Mariângela Tomé. O Reconhecimento como Meio de Prova: Necessidade de reformulação do direito brasileiro. São Paulo: 2011. Tese de Doutorado Faculdade de Direito da Universidade de São Paulo. p. 26
} 


\subsection{Natureza jurídica do reconhecimento}

O reconhecimento tem natureza jurídica de meio de prova, devendo ser realizado não só com a participação das partes, como também diante do juiz, para assim, formar elemento de prova que poderá ser levado em consideração pelo julgador ao decidir.

Importante notar que o reconhecimento teve origem na prova testemunhal, sendo qualificado, inicialmente, como um elemento desta. Nesse sentido, Mariângela Tomé Lopes:

Houve grande evolução nos estudos processuais para se chegar à conclusão de que se trata de meio de prova independente da prova testemunhal, tendo em vista características muito específicas que apresenta este meio de prova. ${ }^{72}$

Esse meio de prova passou a ter previsão expressa no ordenamento jurídico somente com o advento do Código de Processo Penal de 1941, passando então a ser considerado um meio de prova independente.

Sendo assim, o reconhecimento "constitui meio de prova autônomo, apto, portanto, a formar elementos de prova, se realizado em sede judicial, sob o contraditório e com respeito ao procedimento existente extremamente detalhado - para a sua realização". ${ }^{73}$

Nesse contexto, compreendido que o reconhecimento consiste em um meio de prova, importante ainda, classificá-lo dentre a modalidade repetível ou irrepetível de prova.

Estamos, de acordo com o ordenamento jurídico, diante de uma prova repetível, uma vez que seria uma prova passível de reprodução em juízo, já que não haveria que se falar em seu perecimento ou impossibilidade de refazê-la.

\footnotetext{
72 LOPES, Mariângela Tomé. O Reconhecimento como Meio de Prova: Necessidade de reformulação do direito brasileiro. São Paulo: 2011. Tese de Doutorado Faculdade de Direito da Universidade de São Paulo. p 30.

${ }^{73}$ Ibidem. p. 31.
} 
Entretanto, por se tratar de uma prova que pode sofrer influência de diversos fatores que serão apresentados ao longo deste trabalho, mister se faz constatar que o reconhecimento feito uma vez irá interferir na memória da pessoa de tal modo que um segundo reconhecimento já poderia perder o seu valor - afinal, estar-se-ia reconhecendo o suspeito ou o reconhecido em um primeiro momento?

A respeito da impossibilidade de repetir a prova do reconhecimento, Mariângela Tomé Lopes bem pondera:

Este meio de prova, em razão da especial natureza que o reveste, é um ato definitivo e irreprodutível, pois não pode ser repetido em condição idêntica. Esta irrepetibilidade está derivada do fator psicológico preponderante na pessoa chamada a reconhecer.

(...)

Para Eduardo M. Jauchen, o fato de o reconhecedor expressar um juízo de identidade quando the são exibidas pessoas ou coisas, configura experiência que uma vez efetuada e obtido um resultado, positivo ou negativo, tornará ineficaz uma nova realização, pois a imagem incorporada nesse ato interferirá na cadeia de memória da pessoa. Assim, perderia toda a eficácia probatória eventual realização de um segundo reconhecimento.

Assim, o reconhecimento é irreprodutível, pois não pode ser renovado nas mesmas condições. Qualquer novo reconhecimento estará viciado, pois influenciado pelo primeiro. ${ }^{74}$

Sendo assim, resta claro que o ato de reconhecimento deveria ser considerado uma prova irrepetível, tendo em vista a impossibilidade de repeti-lo em condições idênticas.

Para além da irrepetibilidade do ato de reconhecimento, há ainda que se falar no seu caráter de urgência, o que leva à necessidade da realização da produção antecipada desta prova.

Ao se considerar que a memória sofre alterações e que o decurso do tempo influencia nisso e, consequentemente, no ato de reconhecimento, é preciso compreender que essa prova precisa ser produzida antecipadamente.

Isso porque, como já explanado no capítulo anterior, quando há risco de perda dos elementos de prova, esta poderá ser realizada

\footnotetext{
${ }^{74}$ Ibidem, p.32.
} 
antecipadamente, na fase pré-processual, desde que observados os requisitos formais que lhe permitam o status de ato de prova.

Desse modo, "tendo em vista o fato de o tempo afetar diretamente a capacidade de armazenamento de informações, deve o reconhecimento ser realizado como um dos primeiros atos de investigação, antecipando-se a realização do meio de prova". ${ }^{75}$

\subsection{Sujeitos do reconhecimento}

Os sujeitos do reconhecimento consistem em sujeito ativo, sujeito passivo, sujeito de comparação e sujeitos processuais - juiz, defesa e acusação -, todos esses devendo participar do ato.

Acerca do sujeito ativo, este é o agente reconhecedor, trata-se de quem é chamado para realizar a identificação de determinada pessoa ou coisa no ato de reconhecimento, podendo ser a vítima da prática delitiva, uma testemunha ou até mesmo um corréu/coimputado.

No nosso ordenamento, não há previsão expressa acerca de quem pode ser sujeito ativo do ato de reconhecimento, de modo que, por inexistir tratamento específico, qualquer pessoa pode realizar.

Nesse sentido, Mariângela Tomé Lopes afirma que "inobstante qualquer pessoa possa ser sujeito ativo do reconhecimento por falta de limitação legal, insta observar a qualidade de cada um desses indivíduos para efetuar a valoração de seu depoimento dentro do processo ${ }^{76}$."

Quando o reconhecedor for testemunha no processo, importante esclarecer que ele terá o compromisso de dizer a verdade, uma vez que presta juramento, sob a possibilidade de responder pelo crime de falso testemunho, caso inobserve o seu compromisso, mentindo ou omitindo a sua percepção a respeito da pessoa ou coisa objeto do reconhecimento.

\footnotetext{
${ }^{75}$ LOPES, Mariângela Tomé. Op. cit. p. 33

${ }^{76}$ Ibidem. p. 34
} 
Assim, entende-se que "o reconhecedor-testemunha tem todos os deveres de testemunha. Assim, tem por obrigação: 1. Comparecer ao ato de reconhecimento; 2. Responder segundo a verdade". ${ }^{77}$

Já no caso de o reconhecedor ser um coimputado, este "não prestará compromisso de dizer a verdade e possuirá todos os direitos referentes à qualidade de réu, inclusive o do nemotenetur se detegere" ${ }^{78}$

Em relação ao sujeito passivo do reconhecimento, trata-se da pessoa a ser submetida ao ato de reconhecimento para ser identificada, podendo ser não apenas o investigado ou acusado da prática delitiva, mas também alguma testemunha ou, eventualmente, a vítima.

Sendo assim, qualquer pessoa pode ser sujeito passivo do ato de reconhecimento e "a necessidade de reconhecer pessoas diversas do imputado pode surgir para confirmar a presença de testemunhas ou mesmo da vítima no local do crime, bem como para buscar pessoas que possam contribuir com o acervo probatório". ${ }^{79}$

Já no que tange ao sujeito de comparação seriam justamente as pessoas que são submetidas ao ato de reconhecimento juntamente com o suspeito a ser identificado.

Em outras palavras, trata-se de pessoas colocadas na posição do sujeito passivo, sem, contudo, ser investigado. Sendo apenas uma pessoa auxiliando no ato por apresentar características semelhantes às do investigado.

Por fim, os sujeitos processuais que deveriam participar do ato de reconhecimento são o juiz, a defesa e a acusação, uma vez que estamos diante de um ato de prova.

\footnotetext{
${ }^{77}$ Ibidem, p. 34.

${ }^{78}$ Ibidem, p. 35.

79 TRIGGIANI, Nicola, Ricognizionimezzodi prova nelnuovo processo penale. Milão: Editora Giuffrè, 1998. p. 109 apud LOPES, Mariângela Tomé. O Reconhecimento como Meio de Prova: Necessidade de reformulação do direito brasileiro. São Paulo: 2011. Tese de Doutorado Faculdade de Direito da Universidade de São Paulo p. 36
} 
Sendo assim, a presença do juiz é essencial, visto que o destinatário da prova, bem como a presença da acusação e da defesa, para verificarem o cumprimento das formalidades do ato.

Há, no entanto, que se mencionar que não há na nossa legislação previsão expressa acerca do agente responsável pelo ato de reconhecimento.

\subsection{Momento do reconhecimento}

O reconhecimento de pessoas e coisas pode ocorrer tanto durante a investigação, na fase pré-processual, quanto na instrução, na fase processual.

Desse modo, realizado o ato de reconhecimento em sede policial, na fase pré-processual, este estaria condicionado à repetição em juízo, sob o crivo do contraditório e da ampla defesa, para só então ser apto a lastrear eventual sentença condenatória.

Entretanto, como defendemos que o ato de reconhecimento consiste em uma prova irrepetível - em razão da sua natureza e da impossibilidade de se manter inalterada a memória, ainda mais com o decurso do tempo -, o ato deveria ser realizado apenas uma vez, por meio da produção antecipada de prova, observando então as formalidades que permitirão que o ato tenha o status de ato de prova e não de ato de investigação.

\subsection{Fases do reconhecimento}

Feitas essas considerações, insta observar que o reconhecimento, no ordenamento jurídico pátrio, está previsto nos artigos 226 e seguintes do CPP, dispondo esse:

Art. 226. Quando houver necessidade de fazer-se o reconhecimento de pessoa, proceder-se-á pela seguinte forma:

I - a pessoa que tiver de fazer o reconhecimento será convidada a descrever a pessoa que deva ser reconhecida; 
Il - a pessoa, cujo reconhecimento se pretender, será colocada, se possível, ao lado de outras que com ela tiverem qualquer semelhança, convidando-se quem tiver de fazer o reconhecimento a apontá-la;

III - se houver razão para recear que a pessoa chamada para o reconhecimento, por efeito de intimidação ou outra influência, não diga a verdade em face da pessoa que deve ser reconhecida, a autoridade providenciará para que esta não veja aquela;

IV - do ato de reconhecimento lavrar-se-á auto pormenorizado, subscrito pela autoridade, pela pessoa chamada para proceder ao reconhecimento e por duas testemunhas presenciais.

Parágrafo único. O disposto $\mathrm{n}$. III deste artigo não terá aplicação na fase da instrução criminal ou em plenário de julgamento.

Assim, podemos falar em quatro fases do reconhecimento: 1 . Descrição das características da pessoa ou coisa pelo reconhecedor; 2 . Colocação das pessoas ou coisas com características semelhantes às de quem ou do que deverá ser reconhecido; 3. Indicação da pessoa ou coisa por parte do reconhecedor; 4. Elaboração do auto de reconhecimento.

\subsubsection{A primeira fase do reconhecimento}

A primeira fase do reconhecimento diz respeito à descrição das características da pessoa ou coisa a ser reconhecida.

\section{Segundo Mariângela Tomé Lopes:}

Esta fase é de extrema importância, principalmente porque ativa os reflexos da memória. Tem por finalidade verificar se o reconhecedor está atento ao ato e se ele se recorda de algum dado da pessoa ou da coisa que será colocada na sua frente para fins de reconhecimento. ${ }^{80}$

E a autora prossegue, constatando o que é importante se verificar nessa fase:

(i) se o reconhecedor faz mesmo referência àquela pessoa ou coisa a ser reconhecida e (ii) a sua capacidade da memória. A capacidade de memória do reconhecedor e, por conseguinte, a efetividade do reconhecimento, é diretamente proporcional ao seu tempo de contato com a pessoa a ser reconhecida. Quanto

\footnotetext{
${ }^{80}$ LOPES, Mariângela Tomé. Op. cit. p. 51.
} 
mais longo o contato, maior probabilidade de o reconhecimento apresentar resultado confiável. ${ }^{81}$

Além disso, a autora fala em algumas perguntas que deveriam ser realizadas nessa fase do reconhecimento, não havendo, contudo, previsão expressa na lei para que as mesmas sejam de fato realizadas.

\section{A esse respeito:}

Deve-se perguntar, por exemplo, se o reconhecedor já conhecia a pessoa a ser reconhecida, se teve contato com essa pessoa antes ou após os fatos, se o reconhecedor viu a pessoa nos jornais, foto ou algum outro ponto de identificação etc.

Isto porque o contato posterior do reconhecedor com o reconhecido, após os fatos, influi no ato do reconhecimento, na medida em que o sugestiona. Evidentemente, haverá maior facilidade para indicação das características do imputado, se o reconhecedor manteve algum contato após a data dos fatos com aquela pessoa. Por exemplo, se a pessoa a ser reconhecida foi vista em jornal ou na TV, haverá uma probabilidade maior de o resultado do reconhecimento ser positivo, não porque o reconhecedor lembra a sua fisionomia do dia dos fatos, mas porque viu a sua imagem na mídia.

Também para se avaliar o êxito de um reconhecimento e o grau de memorização, deve-se questionar ao reconhecedor qual era a vestimenta do suposto autor no dia do crime. (...)

Outras questões a serem formuladas pelo Juiz na primeira fase do reconhecimento são: se havia boa luz no local dos fatos; se o contato foi próximo ou distante; qual era o seu estado de ânimo no momento dos fatos etc. ${ }^{82}$

Diante disso, resta evidente a importância dessa fase não só para se analisar as características descritas pelo reconhecedor e a sua semelhança com quem será reconhecido, mas também por consistir em uma oportunidade de obter do reconhecedor informações acerca do contato que ele teve com o suspeito e aferir o grau de certeza que ele tem.

Realmente, o contato posterior aos fatos com o suspeito - seja pessoalmente ou até mesmo pela mídia - pode influenciar significativamente na sua memória e fazer com que haja uma identificação errada, sendo importante atentar para isso também.

\footnotetext{
${ }^{81}$ LOPES, Mariângela Tomé. Op. cit. p. 51-52

${ }^{82}$ Ibidem, p. 52.
} 
Assim sendo, aduz-se que a primeira fase é de suma importância, uma vez que se a descrição indicar pessoa diversa daquela a ser reconhecida, não há que se falar no prosseguimento e realização das fases seguintes.

\subsubsection{A segunda fase do reconhecimento}

A segunda fase consiste na colocação de pessoas ou coisas com características semelhantes às de quem ou do que deverá ser reconhecido.

Acerca dessa fase, observa-se que embora o Código de Processo Penal faça menção à possibilidade de colocação do suspeito ao lado de pessoas com características semelhantes, este "não estabelece a obrigatoriedade do procedimento, sanção para o caso de descumprimento, nem ao menos o número de participantes" ${ }^{83}$

Nesse ponto, Aury Lopes Jr. destaca dois aspectos para os quais devemos atentar, são eles o número de pessoas e as semelhanças físicas. A respeito do número de pessoas:

O Código é omisso nessa questão, mas recomenda-se que o número não seja inferior a 5 (cinco), ou seja, quatro pessoas mais o imputado, para maior credibilidade do ato e redução da margem de erro. ${ }^{84}$

Já no que tange às semelhanças físicas necessárias entre a pessoa a ser reconhecida e as demais:

Questão crucial nesse ato é criar um cenário cujo nível de indução seja o menor possível, daí por que deverá o juiz atentar para a formação de uma roda de reconhecimento com pessoas de características físicas similares (estatura, porte físico, cor de cabelo e pele etc.). A questão da vestimenta também deverá ser observada pelo juiz, para que não existam contrastes absurdos entre os participantes. ${ }^{85}$

\footnotetext{
${ }^{83}$ DI GESU, Cristina. Op. cit. p. 162.

${ }^{84}$ LOPES JR., Aury. Direito Processual Penal. São Paulo: Saraiva, 2015. p. 497.

${ }^{85}$ Idem.
} 
Além disso, insta ressaltar que "a pessoa semelhante a ser colocada ao lado do indiciado não pode ser alguém do conhecimento prévio do reconhecedor, para evitar reconhecimento por exclusão". ${ }^{86}$

\subsubsection{A terceira fase do reconhecimento}

A terceira fase do reconhecimento é aquela na qual o sujeito reconhecedor deverá identificar a pessoa envolvida no crime, dentre os sujeitos que lhe são apresentados.

O perigo desta fase mora no receio que a pessoa que vai realizar o ato de reconhecimento normalmente tem, gerando a sensação de obrigatoriedade de apontar alguém como autor do delito. Nesse sentido, Anna Maria Capitta:

O êxito do ato recognitivo pode ser influenciado pela mesma modalidade complexa do procedimento: o reconhecedor está psicologicamente induzido a dizer que entre os sujeitos ali colocados se encontra necessariamente a pessoa a ser reconhecida. ${ }^{87}$

Diante disso, o ideal seria o juiz ou a autoridade que conduza o ato alertar que não há obrigatoriedade de se identificar alguém, somente devendo fazê-lo caso haja certeza, uma vez que um reconhecimento sem o máximo grau de certeza - 100\% - deve ser considerado um reconhecimento negativo.

Nesse sentido, Cristina di Gesu ressalta que:

O reconhecimento é invalidado quando se diz que o sujeito "é parecido" ou "bem parecido" com o réu (desde que não haja outras provas a incriminar o acusado, tais como, p. ex., a apreensão dos bens subtraídos em seu poder, um exame datiloscópico ou de DNA confirmando a autoria) ou então quando a descrição do envolvido não condiz com as características físicas do imputado. ${ }^{88}$

\footnotetext{
${ }^{86}$ LOPES, Mariângela Tomé. Op. cit. p.55

87 CAPITTA, Anna Maria, Ricognizioni e individuazionidipersone..., p. 134 apudLOPES, Mariângela Tomé. O Reconhecimento como Meio de Prova: Necessidade de reformulação do direito brasileiro. São Paulo: 2011. Tese de Doutorado Faculdade de Direito da Universidade de São Paulo.p. 56

${ }^{88}$ DI GESU, Cristina. Op. cit. p. 161.
} 


\subsubsection{A quarta fase do reconhecimento}

A quarta fase consiste naquela em que, após a realização do ato de reconhecimento, consoante a previsão das fases anteriores, há a transcrição e documentação do ato, elaborando-se um auto pormenorizado.

Sendo assim, esse auto detalhado e descritivo acerca do ato de reconhecimento é que "permite observar as falhas existentes ou o respeito total ao rito procedimental. Por isso, sem a devida documentação, o reconhecimento não terá qualquer validade" ${ }^{89}$

\subsection{A inobservância da forma}

Feitas essas considerações acerca do ato de reconhecimento, importante atentar para como este ato deveria, em tese, ocorrer e o modo como há, na prática, a inobservância da forma prevista na lei pela autoridade que realiza.

Primeiramente, importante destacar que, conforme ensina Aury Lopes Jr., o ato de reconhecimento consiste em:

Uma prova cuja forma de produção está estritamente definida e, partindo da premissa que - em matéria processual penal - forma é garantia, não há espaço para informalidades judiciais. Infelizmente, prática bastante comum na praxe forense consiste em fazer "reconhecimentos informais", admitidos em nome do princípio do livre convencimento motivado. ${ }^{90}$

Nesse cenário, há que se esclarecer que apesar de defender que o ato de reconhecimento consiste em um meio de prova irrepetível, fato é que este ato ainda é encarado como um ato repetível, de modo que a realização feita em sede policial não ocorre em consonância com a produção antecipada de provas - isto é, sem a observância dos princípios da ampla defesa e do contraditório, bem como sem a presença do juiz, do Ministério

\footnotetext{
${ }^{89}$ LOPES, Mariângela Tomé. Op. cit. p 57

${ }^{90}$ LOPES JR., Aury. Direito Processual Penal. São Paulo: Saraiva, 2015. p. 496.
} 
Público e da defesa - precisando, desse modo, ser repetida em juízo para adquirir o status de prova.

Assim, o que ocorre na prática é que após a realização do ato de reconhecimento em sede policial, é feita a confirmação da identificação em juízo, por meio do chamado "reconhecimento por indicação".

Acerca do referido reconhecimento por indicação, Aury Lopes Jr. aponta o desprezo à formalidade que decorre dessa simplificação que é feita em juízo:

É uma perigosa informalidade quando o juiz questiona a testemunha ou vítima se "reconhece(m) o(s) réu(s) ali presente(s) como sendo o(s) autor(es) do fato". Essa "simplificação" arbitrária constitui um desprezo à formalidade do ato probatório, atropelando as regras do devido processo e, principalmente, violando o direito de não fazer prova contra si mesmo. Por mais que os tribunais brasileiros façam vista grossa para esse abuso, argumentando às vezes em nome do "livre convencimento do julgador", a prática pode ensejar nulidade. ${ }^{91}$

Acerca da formalidade necessária no ato do reconhecimento, Aury

Lopes Jr. sustenta:

É ato formal que visa a confirmar a identidade de uma pessoa ou coisa. O problema é a forma como é feito o reconhecimento. (...) Logo, não é reconhecimento quando o juiz simplesmente pede para a vítima virar e reconhecer o réu (único presente e algemado...), pois descumpre a forma e é um ato induzido. Contudo, os juízes fazem a título de "livre convencimento", com sério risco de nulidade processual (ilicitude da prova) na medida em que viola o sistema acusatório (gestão da prova nas mãos das partes); quebra a igualdade de tratamento, oportunidades e fulmina a imparcialidade; constitui flagrante nulidade do ato, na medida em que praticado em desconformidade com o modelo legal previsto; e, por fim, nega eficácia ao direito de silêncio e de não fazer prova contra si mesmo. ${ }^{92}$

No mesmo sentido, ao tratar da informalidade que ocorre nos ditos reconhecimentos em juízo, Tourinho discorre:

É comum, entretanto, nas audiências, o Juiz solicitar à vítima ou à testemunha que, olhando o réu ali sentado, proceda ao seu reconhecimento. A nós nos parece que não se trata aqui de verdadeiro reconhecimento, mas de uma "pergunta a mais", mesmo porque a simples presença daquela pessoa no banco dos réus pode levar, em alguns casos, vítima ou testemunha a ser induzida a fazer uma afirmação, preenchendo desse modo um claro na sua memória vendo aquele

\footnotetext{
${ }^{91}$ LOPES JR., Aury. Direito Processual Penal. São Paulo: Saraiva, 2015. p. 496.

${ }^{92}$ Idem.
} 
homem na posição de réu. Intimamente poderia até assim raciocinar: se ele está aqui, sentado no banco dos réus, é porque foi, realmente, o culpado. Observa-se que indagar da testemunha se reconhece o réu ali sentado como sendo o autor do crime não é, tecnicamente, um reconhecimento, mas um prolongamento do seu depoimento. (...) Entretanto, se houver dúvida quanto à identidade, seja na Polícia, seja em juízo, a observância daquelas formalidades é de rigor. Nem teria sentido proferir-se um decreto condenatório se o réu nega ter sido ele o autor do crime eo Magistrado se louva na palavra da vítima ou de uma testemunha que, na audiência, com uma simples vista d'olhos, afirma ter sido ele o autor da infração... ${ }^{93}$

Assim também os ensinamentos de Antonio Magalhães Gomes Filho e Gustavo Henrique Righi Ivahy Badaró, ao ressaltarem que este "apontamento do acusado em audiência" deve ser considerado prova irritual, pois se procura fazer um reconhecimento, sem observar o rito existente para sua realização ${ }^{94}$.

E ainda prosseguem os autores:

O reconhecimento pessoal, tal qual disciplinado no CPP, envolve uma percepção presente e uma pretérita. Há, também, um ato de memória, invocando percepções guardadas na memória, para compará-las como percepções atuais. A única forma de se conferir a percepção pretérita bem como a correspondência entre o confronto das percepções é com a descrição da percepção pretérita, o que não ocorre na simples indicação ou apontamento do acusado. Ao mais, mormente no caso em que o acusado está algemado na sala de audiência, há um forte componente da sugestionabilidade no apontamento, retirando-lhe qualquer valor probatório. ${ }^{95}$

Não se pode dar espaço para discricionariedade por parte da autoridade competente para a realização do reconhecimento, seja em sede policial ou judicial, uma vez que isso deveria ensejar na ilicitude da prova.

Como já explicitado, não é porque o juiz constrói sua convicção a partir do livre convencimento motivado, que este pode conduzir a instrução probatória como bem entende, sobretudo sem observar a formalidade prevista em lei.

\footnotetext{
${ }^{93}$ TOURINHO FILHO, Fernando da Costa. Código de Processo Penal Comentado. 13. ed. rev. e atual. São Paulo: Saraiva, 2010. p. 673-674.

${ }^{94}$ GOMES FILHO, Antonio Magalhães e BADARÓ, Henrique Righilvahy. Prova e sucedâneos de prova no processo penal brasileiro. Revista Brasileira de Ciências Criminais, $\mathrm{n}^{\circ} 65$, São Paulo: Editora Revista dos Tribunais, março-abril 2007. p. 85.

${ }^{95}$ Ibidem, p. 192.
} 
Não se pode tolerar, desse modo, que réus algemados sejam levados à audiência para lá serem "reconhecidos", uma vez que certamente serão, tendo em vista ser o único naquela situação, havendo forte sugestionabilidade, o que viola gravemente as regras processuais.

Outrossim, para além da sugestionabilidade das algemas, o reconhecimento repetido em juízo é extremamente problemático, uma vez que é muito difícil reiterar o ato de reconhecimento em sede judicial com as mesmas pessoas presentes no reconhecimento realizado em sede policial. Logo, a única presença repetida em ambos os caso seria o réu, o que constitui um inequívoco induzimento à identificação deste no ato do reconhecimento. ${ }^{96}$

Acerca da observância da forma como garantia processual, Mariângela Tomé Lopes sustenta que:

A prova que contraria a lei não pode se tornar atípica pela simples admissão do princípio da não taxatividade dos meios de prova e do livre convencimento judicial. Caso haja procedimento expresso em lei para a realização do meio de prova, este deve ser respeitado. ${ }^{97}$

Dito isso, importante reiterar que no direito processual penal, forma é garantia e esta não deve e não pode ser encarada como mero apego ao formalismo, mas sim como uma garantia do cidadão perante o Estado e suas arbitrariedades, de modo que sem a observância da forma, não há como se legitimar a existência e atuação do poder estatal.

Assim sendo, há que se falar que as quatro fases do reconhecimento têm uma explicação para sua existência. "Há razões da Psicologia que explicam a necessidade dessas fases, em virtude da natureza psicológica do reconhecimento". 98

A respeito das fases do ato de reconhecimento e da razão de existir de cada uma delas, Mariângela Tomé esclarece que:

\footnotetext{
${ }^{96}$ LOPES JR., Aury. Direito Processual Penal e sua conformidade constitucional. Vol. I, 2007, p. 632.

${ }_{97}$ Ibidem, p. 87

${ }^{98}$ Idem.
} 
A primeira fase resulta da necessidade de se ativar a memória do reconhecedor e, por meio dela, constata-se o grau de atenção do sujeito ativo. A segunda fase evita sugestionamentos no ato, pois a colocação de outras pessoas de características semelhantes serve para produzir outros elementos de comparação e constatar o grau de certeza do reconhecedor. A terceira fase é justamente o momento em que o reconhecedor vai indicar, entre as pessoas ali expostas, qual seria a envolvida. A quarta fase documenta todas as anteriores. ${ }^{99}$

Ademais, insta esclarecer que, em que pese o inciso II do artigo 226 fale em possibilidade de colocar a pessoa a ser reconhecida ao lado de outras semelhantes - dispõe o inciso que "a pessoa cujo reconhecimento se pretender, será colocada, se possível, ao lado de outras que com ela tiverem qualquer semelhança" -, há que se defender a obrigatoriedade do procedimento.

Isso porque, conforme explanado, além de cada fase do reconhecimento ter uma razão de ser, no processo penal, reitera-se, forma é garantia. Estamos diante de um ato formal e assim, "a interpretação da lei deve ser restrita, pois somente desta forma estar-se-á garantindo a observância das regras do jogo". 100

Dito isso, para além da inobservância à forma no reconhecimento em juízo, há que se falar na inobservância também em sede policial, quando da realização do chamado "reconhecimento fotográfico", uma vez que, dentre inúmeras críticas que podem ser feitas, a foto mostrada à vítima ou à testemunha caracteriza um conhecimento prévio que atrapalha ainda mais o reconhecimento visual presencial e a sua eficácia.

\section{8. $O$ reconhecimento fotográfico}

O reconhecimento fotográfico - modalidade de reconhecimento visual não presencial - consiste em uma diligência policial de uso frequente, diante da carência de suficientes dados identificadores, por meio

\footnotetext{
${ }^{99}$ LOPES, Mariângela Tomé. Op. cit. p. 87

${ }^{100}$ DI GESU, Cristina. Op. cit. p. 160.
} 
do qual se procura orientar a investigação com a apresentação de álbum de fotos de pessoas com passagem policial.

Esse reconhecimento, entretanto, não é tutelado pelo nosso ordenamento jurídico, uma vez que o ideal seria que a pessoa a realizar o reconhecimento descrevesse o suspeito, conforme preceitua o inciso I do artigo 226 do Código de Processo Penal, e não o identificasse em um álbum de fotos, sendo esse ato classificado por parte da doutrina como prova inominada.

Ocorre que, como bem salienta Aury Lopes Jr., ao tratar das provas inominadas:

Deve-se advertir que o fato de admitirmos as provas inominadas tampouco significa permitir que se burle a sistemática legal. Assim, não pode ser admitida uma prova rotulada de inominada quando na realidade ela decorre de uma variação (ilícita) de outro ato estabelecido na lei processual penal, cujas garantias não foram observadas. ${ }^{101}$

Desse modo, sabe-se que o reconhecimento fotográfico deve ser considerado apenas como um ato preparatório do reconhecimento pessoal instrumento-meio -, não podendo ser utilizado como prova substitutiva àquela ou como uma prova inominada.

Nesse sentido, sabe-se que o reconhecimento fotográfico "é um perigoso meio de prova e que tem dado causa a inúmeros casos de erro judiciário. Note-se que a lei cuida do reconhecimento de pessoas e não de fotografia de pessoas". ${ }^{102}$

Dito isso, importante ressaltar que o reconhecimento fotográfico deve ter escassa validade probatória, já que consiste em um instrumento com elevada propensão a erros. Assim, para Huertas Martin:

A situação é agravada quando a fotografia do suspeito passa a ser amplamente difundida pelos meios de comunicação, criando um clima de induzimento extremamente perigoso (prova disso é a quantidade de pessoas que, após a

\footnotetext{
${ }^{101}$ LOPES JR., Aury. Direito Processual Penal. São Paulo: Saraiva, 2015. p. 498.

102 TOURINHO FILHO, Fernando da Costa. Código de Processo Penal Comentado. 13. ed. rev. e atual. São Paulo: Saraiva, 2010. p. 671.
} 
divulgação, passam a afirmar terem visto o agente, ao mesmo tempo, em lugares completamente distantes e diversos). ${ }^{103}$

Sendo assim, há que se falar que a fotografia - mostrada em sede policial ou, eventualmente, veiculada pela mídia - consiste em uma percepção que pode ser fomentadora de erros, uma vez que "quanto mais repetida a percepção, mais complexa e mais precisa ela será. A exatidão da percepção e capacidade de distinguir detalhes depende, geralmente, do conhecimento prévio acerca do objeto ou da pessoa a ser identificada". ${ }^{104}$

A esse respeito, temos a comum situação, na qual é realizado um reconhecimento fotográfico e, posteriormente, um presencial, sendo identificada como autora do fato uma pessoa que na verdade não o é, se tratando de uma recordação da fotografia previamente observada e não do suspeito em si.

Nesse contexto, Neufeld, Brust e Stein exemplificam com um caso no qual o reconhecimento dizia respeito às fotografias apresentadas e não aos autores do delito propriamente dito:

Chamado para fazer uma corrida, um taxista foi vítima de um assalto, no qual sofreu ferimentos e foi levado ao hospital. O investigador do caso mostrou ao taxista, que ainda estava em fase de recuperação, duas fotografias de suspeitos. $\mathrm{O}$ taxista não reconheceu os homens apresentados nas fotos como sendo algum dos assaltantes. Passados alguns dias, quando foi à delegacia para realizar o reconhecimento dos suspeitos, ele identificou dois deles como sendo os autores do assalto. Os homens identificados positivamente eram aqueles mesmos das fotos mostradas no hospital. Os suspeitos foram presos e acusados pelo assalto. Ao ser questionado em juízo sobre o grau de certeza de que os acusados eram mesmo os assaltantes, o taxista declarou: 'eu tenho mais certeza que foram eles, do que meus filhos são meus filhos!' Todavia, alguns meses depois, dois rapazes foram presos por assalto em uma cidade vizinha, quando interrogados, confessaram diversos delitos, incluindo o assalto ao taxista. ${ }^{105}$

\footnotetext{
${ }^{103}$ HUERTAS MARTIN, Maria Isabel. El sujeito Pasivo del Proceso Penal como Objeto de la Prueba. Barcelona, Bosch, 1999, p. 243 apud LOPES JR., Aury, Direito Processual Penal. São Paulo: Saraiva, 2015. p. 498.

${ }^{104}$ DI GESU, Cristina. Op. cit. p. 156.

${ }^{105}$ NEUFELD, Carmen Beatriz et. al. Compreendendo o Fenômeno das Falsas Memórias. In: STEIN, Lilian Milnitsky et. al. Falsas Memórias: Fundamentos Científicos e suas Aplicações Clínicas e Jurídicas. Porto Alegre: Artmed, 2010. p. 22.
} 
Nesse sentido, Altavilla afirma que não pode ser realizado um reconhecimento pessoal posterior ao reconhecimento fotográfico, uma vez que, realizado um reconhecimento sobre fotografia, outro reconhecimento posterior seria inútil, já que a testemunha se limitaria a confrontar a fotografia com a pessoa a ser reconhecida e não a imagem que ficou na sua memória da pessoa vista no momento do delito com aquela que lhe está sendo mostrada. ${ }^{106}$

Em outras palavras, Aury Lopes Jr. diz que "existe a formação de uma imagem mental da fotografia, que culmina por comprometer o futuro reconhecimento pessoal. Trata-se de uma experiência visual comprometedora". ${ }^{107}$

Desse modo, a percepção precedente ocorre quando estamos diante de formas antecedentes ao reconhecimento direto, em situações não previstas pela legislação - como o reconhecimento por foto -, de forma que "a experiência passada, que deixou suas impressões na nossa memória, completa continuamente a nossa experiência presente" ${ }^{108}$, gerando assim, erros na percepção atual.

Nesse contexto, importante ainda falar do "efeito compromisso", este ocorre quando há uma identificação incorreta, por exemplo, quando a pessoa analisa muitas fotografias e identifica o sujeito incorreto e, posteriormente, ao realizar o reconhecimento pessoal presencial, devido à tendência de manter o compromisso anterior, ela mantém a escolha acerca da identificação, mesmo que haja dúvidas. ${ }^{109}$

Além da percepção precedente, há ainda que se observar que as fotografias "não representam a imagem atual e nem a completude da

\footnotetext{
${ }^{106}$ ALTAVILLA, Enrico. Psicologia giudiziaria. Il processo psicológico e laveritàgiudiziale. Editora UnioneTipograficoEditriceTorinese, Tomo I, p. 357-358 apud LOPES, Mariângela Tomé. Op. cit. p. 112

${ }^{107}$ LOPES JR., Aury. Direito Processual Penal. São Paulo: Saraiva, 2015. p. 502.

${ }^{108}$ ALTAVILLA, Enrico. Psicologia Judiciária. Vol. I, 1945, p. 24. Apud DI GESU, Cristina. Op. cit. p. 158.

${ }^{109}$ LOPES JR., Aury. Direito Processual Penal. São Paulo: Saraiva, 2015. p. 502.
} 
pessoa" "110, na medida em que se constituem "em uma representação estática, a qual restitui apenas uma parte dos estímulos presentes numa visão dinâmica". ${ }^{111}$

Dito isso, insta destacar que a situação se agrava ainda mais quando observamos que os atos de reconhecimento realizados no Brasil, em sua grande maioria, são feitos sem a presença do advogado do suspeito e sem oportunizá-lo a recusa à participação no ato.

E mais, no caso de recusa do investigado e admissibilidade da sua recusa, muitas vezes, realiza-se o reconhecimento fotográfico, em clara violação ao direito de silêncio e de não produzir provas contra si do investigado.

Isto é, o investigado tem direito de "negar-se a participar, no todo ou em parte, do ato, sem que dessa recusa se presuma ou extraia qualquer consequência que lhe seja prejudicial". ${ }^{112}$

Desse modo, tem-se que o investigado pode se recusar a participar tanto do reconhecimento presencial, quanto do fotográfico e isso deve ser observado, uma vez que estamos falando de direitos que lhe assistem.

Outro ponto que também merece atenção, embora pouco discutido na doutrina, é a impossibilidade de alteração das características físicas do investigado em sua foto, por meio de programas informatizados com tecnologia para, por exemplo, raspar a barba, cortar o cabelo, pintá-lo, entre outras mudanças nos atributos físicos, ou ainda, a emissão de sons buscando uma maior aproximação daquilo que foi vivenciado durante a prática delitiva. ${ }^{113}$

\footnotetext{
${ }^{110}$ GIACOMOLLI, Nereu José. A fase preliminar do processo penal: crises, misérias e novas metodologias investigativas, 2011, p. 164.

${ }^{111}$ PRIORI, Silvia apud GIACOMOLLI, Nereu José. A fase preliminar do processo penal: crises, misérias e novas metodologias investigativas, 2011, p. 164.

${ }^{112}$ LOPES JR., Aury. Direito Processual Penal. São Paulo: Saraiva, 2015. p. 499.

${ }^{113}$ Idem.
} 
Diante do que fora explanado acerca do reconhecimento fotográfico, conclui-se que este deve ser evitado, não só pela inobservância à forma, já que não há previsão para a realização do mesmo, como também porque, como visto, esse reconhecimento pode contaminar, poluir e deturpar a memória.

Entretanto, apesar da posição aqui sustentada, há que se considerar que os tribunais superiores brasileiros vêm admitindo essa espécie de reconhecimento, desde que observadas as formalidades contidas no artigo 226 do Código de Processo Penal, ou, mesmo que não observadas em sede policial, as irregularidades fossem sanadas em juízo, sob o crivo do contraditório e da ampla defesa, considerando a independência formal entre inquérito e processo.

Nesse sentido, o Superior Tribunal de Justiça em sede de habeas corpus decidiu:

PROCESSUAL PEMAL. HABEAS CORPUS. REVISÃO CRIMINAL. FURTO QUALIFICADO. RECONHECIMENTO FOTOGRÁFICO EM SEDE POLICIAL. INOBSERVÂNCIA DAS FORMALIDADES CONTIDAS NO ART. 226 DO CPP. RECONHECIMENTO PESSOAL FEITO EM JUÍZO. IRREGULARIDADE SANADA SOB O CRIVO DO CONTRADITÓRIO E DA AMPLA DEFESA. PRECEDENTES DO STJ E STF. ALTERAÇÃO DO REGIME INICIAL DE CUMPRIMENTO DE PENA. MATÉRIA NÃOANALISADA PELO TRIBUNAL DE ORIGEM. SUPRESSÃO DE INSTÂNCIA. ORDEM PARCIALMENTE CONHECIDA E, NESSA EXTENSÃO, DENEGADA.

1.A jurisprudência do Superior Tribunal de Justiça admite a possibilidade de reconhecimento do acusado por meio fotográfico desde que observadas as formalidades contidas no art. 226 do Código de Processo Penal.

2. Eventual irregularidade cometida no inquérito policial restou sanada na fase judicial, porquanto o juiz processante, ao realizar o reconhecimento pessoal do acusado na audiência de inquirição de testemunhas, o fez sob o crivo do contraditório e da ampla defesa.

3. Não tendo a controvérsia relativa à alteração do regime de cumprimento de pena sido objeto de debate e julgamento por parte do Tribunal de origem, o exame da matéria pelo Superior Tribunal de Justiça, em sede de habeas corpus, ocasionaria indevida supressão de instância.

4. Ordem parcialmente conhecida e, nessa extensão, denegada.

(HC 136.147/SP, Rel. Min. Arnaldo Esteves Lima, $5^{\text {a }}$ Turma, j. 06/10/2009, DJe 03/11/2009). 
Importante salientar que a decisão acima foi exarada em um caso no qual o reconhecimento fotográfico em sede policial, segundo a defesa, ocorreu sem a presença da suspeita, que poderia e deveria ter sido levada para o reconhecimento; somente mostrando fotografias dela, sem fotos de outras pessoas semelhantes; e, por fim, sem a elaboração do auto de reconhecimento fotográfico.

Desse modo, não resta dúvidas de que esse reconhecimento deveria ser considerado nulo, uma vez que em flagrante inobservância às formalidades previstas no artigo 226 do Código de Processo Penal.

Entretanto, conforme consta no referido julgado, entendeu-se que as irregularidades podem e são sanadas em juízo, sob o crivo do contraditório e da ampla defesa.

E no mesmo sentido decide o Supremo Tribunal Federal:

Habeas corpus. Roubo majorado. Alegada nulidade do processo por conter reconhecimento fotográfico realizado sem a presença do paciente. Ausência de requisição de réu preso para audiência de inquirição de testemunhas. Nulidade relativa. Alegação extemporânea e ausência de prejuízo. Alegação de inversão da ordem de colheita da prova oral. Apreciação per saltum. Impossibilidade. Supressão de instância. Ordem conhecida em parte e denegada.

I - O reconhecimento fotográfico do acusado, quando ratificado em juízo, sob a garantia do contraditório e da ampla defesa, pode servir como meio idôneo de prova para lastrear o édito condenatório. Ademais, como na hipótese dos autos, os testemunhos prestados em juízo descrevem de forma detalhada e segura a participação do paciente no roubo. Precedentes.

II - Tratando-se de réu preso, a falta de requisição para o comparecimento à audiência de oitiva de testemunhas realizada em outra comarca acarreta nulidade relativa, devendo ser arguida em momento oportuno e provado o prejuízo, o que não ocorreu nos autos. Precedentes.

III - Demais alegações não foram suscitadas nas instâncias antecedentes e sua apreciação originária pelo Supremo Tribunal implicaria inadmissível supressão de instância. Questões, ademais, que, por envolver reexame de matéria de fato, mostram-se insuscetíveis de apreciação no caso concreto pela via do habeas corpus. Precedentes.

IV - Ordem conhecida em parte e, na parte conhecida, denegada.

(HC 104.404/MT, Rel. Min. Dias Toffoli, $1^{\text {a }}$ Turma, j. 21/09/2010, DJe $30 / 11 / 2010)$

Ocorre que, o Superior Tribunal de Justiça não só se posicionou no sentido de que o reconhecimento fotográfico seria válido - mesmo que 
irregular em sede policial - quando ratificado em juízo, mas também no sentido de que o disposto no artigo 226 do Código de Processo Penal configura uma recomendação legal e não uma exigência absoluta.

Senão vejamos:

AGRAVO REGIMENTAL NO AGRAVO EM RECURSO ESPECIAL. JÚRI. PRONÚNCIA. EXCESSO DE LINGUAGEM. INEXISTÊNCIA. VIOLAÇÃO DO ART. 226 DO CPP. AUSÊNCIA. FORMALIDADES. RECOMENDAÇÃO LEGAL. AGRAVO REGIMENTAL DESPROVIDO.

1. Não há que se falar, no caso, em excesso de linguagem, porquanto o magistrado em nenhum momento afirmou juízo de certeza acerca da autoria delitiva, mas apenas indicou as provas, em especial testemunhais (e-STJ fls. $630 \mathrm{e}$ 633), que davam suporte à sua conclusão acerca da existência dos indícios em desfavor do recorrente.

2. O Tribunal estadual afirmou que o reconhecimento operado em juízo é válido e observou as regras do referido artigo. A desconstituição dessa conclusão não pode ser alterada em recurso especial ante o óbice do Enunciado n. 7 da Súmula deste Tribunal.

3. Ademais, as disposições insculpidas no art. 226 do CPP, configuram uma recomendação legal, e não uma exigência absoluta, não se cuidando, portanto, de nulidade quando praticado o ato processual (reconhecimento pessoal) de modo diverso. Precedentes.

4. Agravo regimental desprovido.

(AgRg no AREsp 1291275/RJ, Rel. Min. Reynaldo Soares da Fonseca, $5^{\text {a }}$ Turma, j. 02/10/2018, DJe 11/10/2018)

Tal posicionamento que começou a ser adotado pelo STJ no ano de 2018 é estapafúrdio e desarrazoado, uma vez que, como amplamente demonstrado, forma é garantia no processo penal, não podendo se admitir que o artigo 226 do CPP seja visto apenas como uma "recomendação legal".

Desse modo, embora a jurisprudência pátria não corrobore o posicionamento aqui adotado, o reconhecimento fotográfico deve ser evitado, uma vez que, na maioria das vezes, é realizado sem a observância da forma e ainda, propicia o desencadeamento de erros em posterior reconhecimento presencial.

Analisado o ato de reconhecimento e já ventilado que há fatores que influenciam diretamente na qualidade e eficácia desse ato, seja presencial 
ou não, importante se faz tratar do fenômeno das falsas memórias e dos demais moduladores que influenciam no reconhecimento. 


\section{CAPÍTULO 3 - AS FALSAS MEMÓRIAS E 0 RECONHECIMENTO}

\subsection{A memória}

Antes de se analisar o fenômeno das falsas memórias e sua influência no ato do reconhecimento, mister se faz uma breve análise acerca da memória em si.

Primeiramente, insta ressaltar que as imagens não são permanentemente retidas na memória, "na medida em que qualquer tipo de “cópia"geraria problemas de capacidade de armazenamento, devido à imensa gama de conhecimentos adquiridos ao longo da vida". ${ }^{114}$

Nesse sentido, Antônio Damásio explica:

As imagens não são armazenadas sob forma de fotografias facsimilares de coisas, de acontecimentos, de palavras ou de frases. O cérebro não arquiva fotografias Polaroid de pessoas, objetos, paisagens; não armazena fitas magnéticas com música e fala; não armazena filmes de cenas de nossa vida; nem retém cartões com 'deixas' ou mensagens de teleprompter do tipo daquelas que ajudam os políticos a ganhar a vida. (...) Se o cérebro fosse uma biblioteca, esgotaríamos suas prateleiras à semelhança do que acontece nas bibliotecas. ${ }^{115}$

Desse modo, a memória, segundo Ivan Izquierdo, "é a aquisição, a formação, a conservação e a evocação de informações e (...) o acervo de nossas memórias faz com que cada um de nós seja o que é, (...) um ser para o qual não existe outro idêntico" 116 e pode ser classificada em dois grupos: memória procedural e memória declarativa.

A memória procedural é aquela ligada ao aprendizado de atividades como andar de bicicleta, tocar instrumentos, nadar, etc. Isto é, informações

\footnotetext{
${ }^{114}$ LOPES JUNIOR, Aury; GESU, Carla Cristina Di. Falsas memórias e prova testemunhal no processo penal: em busca da redução de danos. In: Revista de Estudos Criminais, Ano VII, n. 25. Sapucaia do Sul: 2007, p. 61.

${ }_{115}$ DAMÁSIO, Antônio. O Erro de Descartes: emoção, razão e o cérebro humano. Trad. Portuguesa Dora Vicente e Georgina Segurado. São Paulo: Companhia das Letras, 1996, p. 128129.

${ }^{116}$ IZQUIERDO, Ivan. Memória. Porto Alegre: Artmed, 2006. p. 09.
} 
são retidas pelo cérebro e reproduzidas através de uma habitualidade motora ou sensorial que se estabelece pela repetição do ato.

Já a memória declarativa faz alusão à memória de fatos, eventos, pessoas, faces, conceitos e ideias, sendo então, de grande importância para a compreensão das falsas memórias.

Acerca da memória declarativa, Lopes Jr. e Di Gesu ressaltam:

Um ponto de suma importância para o estudo diz respeito ao esquecimento dos detalhes ao longo do tempo, quando se trata, por exemplo, de uma tragédia. Logo que o fato acontece, as pessoas lembram do acontecimento com riqueza de detalhes (mas sempre será uma "parte", o fragmento do todo, que é inapreensível para nós). Contudo, com o passar do tempo, estes são esquecidos, mas fica a lembrança do momento dramático. ${ }^{117}$

Diante disso, temos que a memória pode sofrer distorções, não sendo fidedigna à realidade, uma vez que, em decorrência de processos internos e externos, podem ocorrer erros na recepção de informações, motivo pelo qual surgem os estudos acerca das falsas memórias.

\subsection{As falsas memórias}

\subsubsection{Histórico}

O termo "falsas lembranças" foi cunhado em 1881, por Theodule Ribot, a partir de um estudo de caso realizado em Paris com um homem chamado Louis, de 34 anos, que teria tido recordações de fatos nunca ocorridos, o que acabou por despertar o interesse de psiquiatras e psicólogos. $^{118}$

Os primeiros experimentos que demonstraram a ilusão ou falsificação da lembrança, contudo, foram realizados apenas no início do século XX com crianças, mais especificamente por Binet em 1900, na

\footnotetext{
${ }^{117}$ LOPES JR., Aury; GESU, Cristina Di. Falsas memórias e prova testemunhal no processo penal: em busca da redução de danos. In: Revista de Estudos Criminais, Ano VII, n. 25. Sapucaia do Sul: 2007. p. 61.

${ }^{118}$ DI GESU, Cristina. Op. cit. p. 128.
} 
França e Stern em 1910, na Alemanha, já os experimentos em adultos tomaram lugar apenas em 1932, por Barlett, na Inglaterra. ${ }^{119}$

Todavia, foi mais tarde, em 1970, que os estudos tiveram um avanço significativo, com Elizabeth Loftus, quando esta introduziu uma nova técnica para o estudo das falsas memórias. Sobre seus estudos, Cristina di Gesu:

\begin{abstract}
A nosso ver, o que fez dela uma das maiores autoridades sobre o assunto, foi justamente a introdução de uma nova técnica para o estudo das falsas memórias, consistente na sugestão da falsa informação, o que denominou de Procedimento de Sugestão de Falsa Informação ou Sugestão, isto é, uma releitura do clássico paradigma da interferência, no qual "uma informação interfere ou atrapalha a codificação e posterior recuperação de outra". Cuida-se da inserção de uma informação não verdadeira em meio a uma experiência realmente vivenciada ou não, produzindo o chamado efeito "falsa informação", no qual o sujeito acredita verdadeiramente ter passado pela experiência falsa. A autora constatou e identificou a problemática como ela é entendida hoje. ${ }^{120}$
\end{abstract}

Em seus experimentos com mais de 20 mil pessoas, Loftus constatou que "a informação errônea pode se imiscuir em nossas lembranças quando falamos com outras pessoas, somos interrogados de maneira evocativa ou quando uma reportagem nos mostra um evento que nós próprios vivemos". ${ }^{121}$

Dito isso, podemos tratar das teorias explicativas das falsas memórias, dos estudos acerca dos mecanismos de elaboração das mesmas, das pessoas que poderiam ser sugestionadas ou se há predisposição física ou emocional para o seu desenvolvimento.

\title{
3.2.2. Teorias explicativas das falsas memórias
}

Existem três teorias explicativas das falsas memórias: Teoria do Paradigma Construtivista, Teoria do Monitoramento da Fonte e Teoria do

\footnotetext{
${ }^{119}$ DI GESU, Cristina. Op. cit. p. 127-128.

${ }^{120} \mathrm{Idem}$.

${ }^{121}$ LOFTUS, Elizabeth. As falsas lembranças, in: Viver mente \& cérebro, p. 90.
} 
Traço Difuso. Sendo esta última a que melhor explica o fenômeno das falsas memórias.

Para a teoria do paradigma construtivista, há um único sistema de memória, sendo as falsas memórias decorrentes de um processo de interpretação da informação.

Sendo assim:

A memória resultante do processo de reconstrução seria aquilo que as pessoas entendem sobre a experiência, seu significado e não a experiência propriamente dita (...) a memória é construtiva: cada nova informação é compreendida e reescrita (ou reconstruída) com base em experiências prévias. ${ }^{122}$

Já a teoria do monitoramento da fonte surge para explicar e superar a fragilidade da teoria anteriormente mencionada, esta, por sua vez, entende que as falsas memórias "decorrem de um julgamento equivocado da fonte da informação lembrada". ${ }^{123}$ Assim, as falsas memórias não seriam fruto de distorção da lembrança, mas sim "atribuições errôneas da fonte da informação lembrada por erro de julgamento". ${ }^{24}$

Por fim, a teoria do traço difuso surge explicando o fenômeno das falsas memórias de forma diferente. Para essa teoria, a memória não consiste em um sistema unitário, mas sim de múltiplos traços. Assim, Lilian Stein explica que "os erros da memória estariam vinculados à falha de recuperação de memórias precisas e literais acerca de um evento, sendo as falsas memórias baseadas em traços que traduzem somente a essência semântica do que foi vivido". 125

Dito isso, podemos dizer que o processo de formação das falsas memórias é um fenômeno que existe no quotidiano e que ocorre no funcionamento saudável - e não patológico - da memória.

\footnotetext{
${ }^{122}$ NEUFELD, Carmen Beatriz et. al. Compreendendo o Fenômeno das Falsas Memórias. In: STEIN, Lilian Milnitsky et. al. Falsas Memórias: Fundamentos Científicos e suas Aplicações Clínicas e Jurídicas. Porto Alegre: Artmed, 2010. p. 27.

${ }^{123}$ DI GESU, Cristina, Op. Cit. p. 139.

${ }^{124}$ NEUFELD, Carmen Beatriz et. al. Compreendendo o Fenômeno das Falsas Memórias. In: STEIN, Lilian Milnitsky et. al. Falsas Memórias: Fundamentos Científicos e suas Aplicações Clínicas e Jurídicas. Porto Alegre: Artmed, 2010. p. 30.

${ }^{125}$ Ibidem, p. 30-31.
} 


\subsubsection{O processo de elaboração das falsas memórias}

Importante ainda, ressaltar que as falsas memórias podem ser provenientes de sugestões externas ou podem surgir de forma espontânea, como "resultado do processo normal de compreensão, ou seja, fruto de processos de distorções mnemônicas endógenas". ${ }^{126}$

Acerca disso, sustenta-se que:

As falsas memórias espontâneas ou autossugeridas são resultantes de distorções endógenas e ocorrem quando a lembrança é alterada internamente, fruto do próprio funcionamento da memória, sem interferência de uma fonte externa à pessoa. Neste caso, uma inferência ou interposição pode passar a ser lembrada como parte da informação original e comprometer a fidedignidade do que é recuperado. (...) No que tange às falsas memórias sugeridas, elas advêm da sugestão da falsa informação externa ao sujeito, ocorrendo devido à aceitação de uma falsa informação posterior ao evento e a subsequente incorporação na memória original. Esse fenômeno, denominado efeito da sugestão da falsa informação, pode ocorrer tanto de forma acidental quanto de forma deliberada. Nas falsas memórias sugeridas, após presenciar um evento, transcorre-se um período de tempo no qual uma nova informação é apresentada como fazendo parte do evento original, quando na realidade não faz. ${ }^{127}$

O estudo das falsas memórias, assim, centra-se na indução ou sugestionamento, devido à influência dos fatores externos na formação do fenômeno, sem desconsiderar, contudo, as falsas memórias espontâneas, já que estas também podem contaminar uma prova processual.

Desse modo, podemos dizer que o sugestionamento, em regra, ocorre nas situações em que é demandado da pessoa que ela recorde fatos vivenciados, como, por exemplo, o reconhecimento do suspeito do cometimento de um crime ou o depoimento de uma testemunha. Acerca disso, Daniel Schaeter afirma:

A sugestionabilidade é preocupante por várias razões: perguntas tendenciosas podem ajudar a levar testemunhas a fazer identificações erradas; técnicas terapêuticas sugestivas podem ajudar a criar falsas lembranças; e interrogatórios agressivos de crianças pequenas podem resultar em lembranças distorcidas de supostos abusos por professores e outros adultos. As consequências para os indivíduos envolvidos em casos como esses são muito sérias e, portanto, a

\footnotetext{
${ }^{126}$ STEIN, Lilian Milnilsky e PERGHER, Giovanni Kuckartz. Criando falsas memórias em adultos por meio de palavras associadas, in Psicologia: Reflexão e Crítica, p. 354.

${ }^{127}$ NEUFELD, Carmen Beatriz et. al. Op. Cit, 2010. p. 27.
} 
compreensão e o combate à sugestionabilidade são importantes tanto para evitar problemas sociais e jurídicos quanto para o avanço da teoria psicológica. ${ }^{128}$

Além disso, há ainda que se falar que algumas pessoas são mais propensas ao desenvolvimento das falsas memórias. Essa suscetibilidade, normalmente, ocorre para crianças e para aquelas pessoas que sofreram algum tipo de trauma, evidenciando-se a estreita relação entre memória e emoção.

Sendo assim, através da observação casuística e de estudos de experimentações, constatou-se que "as crianças foram historicamente avaliadas como vulneráveis à sugestão, pois a tendência infantil é justamente a de corresponder às expectativas do que deveria acontecer, bem como às expectativas do adulto entrevistador". ${ }^{129}$

Ademais, importante esclarecer que as falsas memórias não se confundem com a mentira. Nas palavras de Lilian Stein:

As Falsas Memórias não são mentiras ou fantasias das pessoas; elas são semelhantes às memórias verdadeiras, tanto no que tange a sua base cognitiva quanto neurofisiológica. No entanto, diferenciam-se das verdadeiras pelo fato de as Falsas Memórias serem compostas, no todo ou em parte, por lembranças de informações ou de eventos que não ocorreram na realidade. É fenômeno fruto do funcionamento normal, não patológico, de nossa memória. ${ }^{130}$

Dito isso, podemos analisar a influência das falsas memórias ao submeter uma pessoa à identificação de outra no ato de reconhecimento realizado como prova no processo penal.

\footnotetext{
${ }^{128}$ SCHACTER, Daniel L. Os Sete Pecados da Memória: Como a Mente Esquece e Lembra. Rio de Janeiro: Rocco, 2003. p.143.

${ }^{129}$ LOPES JUNIOR, Aury; GESU, Carla Cristina Di. Falsas memórias e prova testemunhal no processo penal: em busca da redução de danos. In: Revista de Estudos Criminais, Ano VII, n. 25. Sapucaia do Sul: 2007. p. 65.

${ }^{130}$ NEUFELD, Carmen Beatriz et. al. Compreendendo o Fenômeno das Falsas Memórias. In: STEIN, Lilian Milnitsky et. al. Falsas Memórias: Fundamentos Científicos e suas Aplicações Clínicas e Jurídicas. Porto Alegre: Artmed, 2010. p.36.
} 


\subsection{A influência das falsas memórias no ato de reconhecimento}

Analisado os aspectos fundamentais para a melhor compreensão do fenômeno das falsas memórias, podemos fazer tratar da influência desta no ato de reconhecimento.

Como se sabe, as provas no processo penal fazem uma reconstrução histórica do fato delitivo, mas, na grande maioria das vezes, pela ausência de outros elementos - por não terem sido colhidos e, consequentemente, apagados pelo tempo ou por não serem crimes que deixam vestígios dependem da memória das pessoas que os narram.

O reconhecimento de pessoas é prova eminentemente cognitiva, sendo extremamente passível de erros, uma vez que o fenômeno das falsas memórias pode ocorrer e comprometer a confiabilidade do ato.

Assim, conforme já explanado, o Código de Processo Penal, ao regulamentar o ato de reconhecimento, dispõe que os indivíduos a serem reconhecidos devem ser apresentados simultaneamente, de forma enfileirada, para que, quando observados em conjunto pela pessoa a realizar o reconhecimento, possa ser identificado e apontado o suposto autor do fato, sendo este procedimento considerado altamente sugestivo:

A identificação por testemunhas oculares a partir dos desfiles ou fileiras de identificação é, em geral, muito falível. Valentine e seus colaboradores estudaram as evidências de 640 testemunhas oculares que tentaram identificar suspeitos em 314 line-ups (enfileiramento de suspeitos para serem identificados) reais. Cerca de $20 \%$ das testemunhas identificaram um não suspeito, $40 \%$ identificaram o suspeito e $40 \%$ falharam em fazer a identificação. Um das razões mais importantes para a identificação inacurada da testemunha ocular é que somos, com frequência, surpreendentemente deficientes no reconhecimento de rostos não familiares. ${ }^{131}$

Importante ressaltar, contudo, que não se procura descredibilizar o ato de reconhecimento, mas tão somente apontar que essa prova, por si só, não deve ser suficiente para embasar a condenação de alguém, já que a memória é altamente suscetível de erros e vícios.

\footnotetext{
${ }^{131}$ EYSENCK, Michael W.; KEANE, Mark T. LOPES, Magda França.(Trad.). Manual de Psicologia Cognitiva. $5^{\text {a }}$ ed. Porto Alegre: Artmed, 2007, p. 279.
} 
Para Mariângela Tomé Lopes, a memória pode sofrer alterações a depender de dois aspectos: “1. O estado psicológico que a pessoa se encontrava no momento dos fatos; 2 . O passar do tempo é capaz de apagar informações importantes ou de criar falas memórias", 132

Assim, conforme afirmado por Lilian Stein ${ }^{133}$, as informações providas por outras pessoas, especialmente após um evento altamente estressante, poderão influenciar na interpretação e percepção daquele que irá reconhecer o suposto autor do delito, sendo estas as falsas memórias provenientes de sugestões externas.

Nesse sentido, a autora prossegue, criticando a forma como o ato do reconhecimento é realizado, pois a memória seria um sistema único construído a partir da interpretação que as pessoas fazem do evento, ou seja, seria aquilo que as pessoas entendem sobre a experiência, seu significado, e não a experiência propriamente dita. ${ }^{134}$

Dito isso, Nereu José Giacomolli explica as alarmantes estatísticas de erros quando a prova baseia-se somente no reconhecimento:

Estatísticas revelam que num marco de dez anos, nos EUA, de quarenta casos em que houve condenações pelo reconhecimento do réu, em trinta e seis deles a autoria foi afastada depois de submissão ao exame de DNA. A única prova era o reconhecimento. ${ }^{135}$

Nesse cenário, há que se salientar que a busca desmedida pela "verdade real" no processo penal, anteriormente melhor esclarecida, acaba influenciando a memória das pessoas que realizam ato de reconhecimento na investigação criminal ou na instrução probatória, uma vez que se sentem compelidas a identificar, de fato, alguém e a auxiliar na busca dessa verdade.

\footnotetext{
${ }^{132}$ LOPES, Mariângela Tomé. Op. cit. p.33.

${ }^{133}$ STEIN, Lilian Milsnitskyet. et al. Falsas memórias: fundamentos científicos e suas aplicações clínicas e jurídicas. Porto Alegre: Artes Médicas, 2010. p. 26.

${ }^{134}$ Ibidem, p. 27.

135 GIACOMOLLI, Nereu José. A fase preliminar do processo penal: crises, misérias e novas metodologias investigativas, 2011, p. 156.
} 
Sabemos que a verdade real é inalcançável, uma vez que há a impossibilidade de reconstrução do fato ou da imagem tal como aconteceu. A esse respeito, Di Gesu afirma:

É claro que o "ideal" seria a colheita e análise do conjunto probatório totalmente despido dos riscos endógenos (internos) e exógenos (externos ao processo). Contudo, isso está fora de cogitação, pois as pessoas não vivem em uma redoma de vidro, completamente isoladas de influências externas ou estanques às modificações no tempo. E mesmo que assim fosse, a própria memória e a imaginação poderiam trair a ideia de representação exata do acontecimento. ${ }^{136}$

Além disso, nesse contexto, importante ainda tratar da chamada "transferência inconsciente". Esta ocorre quando a vítima ou testemunha indicam uma pessoa que viram, em momento concomitante ou próximo àquele em que ocorreu o crime, dentro do crime, geralmente como autor. ${ }^{137}$ Isto é, essa transferência faz com que a pessoa que está a realizar o reconhecimento assuma, inconscientemente, que uma pessoa que nada tinha a ver com a prática delitiva, estava participando dela e, geralmente, como autora.

Assim sendo, o ato de reconhecimento, embora um dos meios mais comuns de prova, consiste em um meio de prova evidentemente frágil e falho, o que decorre não somente do fenômeno das falsas memórias que influenciam significativamente na identificação do suspeito, mas também de outros fatores que serão expostos adiante.

\footnotetext{
${ }^{136}$ GIACOMOLLI, Nereu José; DI GESU, Cristina Carla. As Falsas Memórias na Reconstrução dos Fatos pelas Testemunhas no Processo Penal. p. 4341. (Trabalho publicado nos Anais do XVII Congresso Nacional do CONPEDI, realizado em Brasília - DF nos dias 20, 21 e 22 de novembro de 2008).

${ }^{137}$ LOPES JR., Aury. Direito Processual Penal. São Paulo: Saraiva, 2015. p. 501.
} 


\section{CAPÍTULO 4 - A FRAGILIDADE E FALIBILIDADE DO RECONHECIMENTO COMO PROVA}

Como dito, a prova obtida pelo reconhecimento de pessoa é uma prova muito frágil e também falha, isto é, para além das falsas memórias, diversos fatores podem influenciar no ato, tais como o transcurso do tempo, a inobservância de algum dos requisitos formais previstos, o fato de uma fotografia de um "suspeito" ter sido mostrada antes do reconhecimento presencial, o anseio punitivo de encontrar o culpado pelo crime praticado, a semelhança física, entre outros.

Acerca da fragilidade da prova obtida pelo reconhecimento, Tourinho afirma que:

De todas as provas previstas no nosso diploma processual penal, esta é a mais falha, a mais precária. A ação do tempo, o disfarce, más condições de observação, erros por semelhança, a vontade de reconhecer, tudo, absolutamente tudo, torna o reconhecimento uma prova altamente precária. ${ }^{138}$

Nesse sentido, a probabilidade de erros no reconhecimento é decorrente do fato de as experiências passadas deixarem suas impressões na memória, podendo esta apresentar equívocos ao reconhecer o suspeito do cometimento de algum delito, as chamadas falsas memórias já abordadas.

Segundo Aury Lopes Jr., além das falsas memórias, diversos fatores podem prejudicar o reconhecimento, como, por exemplo, estar o criminoso com o rosto encoberto por touca ou capacete, não ter a vítima obtido contato direto com o mesmo, ou até mesmo o chamado "efeito do foco na arma" que é "decisivo para que a vítima não se fixe nas feições do agressor, pois o fio condutor da relação de poder que ali se estabelece é a arma"139, devendo essa variável - qual seja o emprego de arma - ser considerada altamente prejudicial para o reconhecimento positivo.

\footnotetext{
${ }^{138}$ TOURINHO FILHO, Fernando da Costa. Código de Processo Penal Comentado. 13. ed. rev. e atual. São Paulo: Saraiva, 2010.p. 671-672.

${ }^{139}$ LOPES JR., Aury. Direito Processual Penal. São Paulo: Saraiva, 2015. p. 501.
} 
Além disso, outras diversas moduladoras concorrem para piorar a qualidade da identificação, tais como o tempo da exposição da vítima ao crime e ao contato com o agressor, a gravidade do fato (memória está intimamente ligada à emoção), o intervalo de tempo entre o delito e a realização do reconhecimento, as condições ambientais (visibilidade, aspectos geográficos), as condições psíquicas da vítima (memória, estresse, nervosismo), as características do agressor (mais ou menos marcantes), a natureza do delito (com ou sem o emprego de violência física, o grau da violência psicológica empregada), entre outros. ${ }^{140}$

Acerca dessas moduladoras, Altavilla ressalta que a maior parte dos erros do reconhecimento decorre das condições em que a primeira impressão é absorvida, sendo assim:

Os fatores rapidez do contato, condições de luz no momento dos fatos, distância que teria visto a pessoa ou coisa, posição da pessoa e condições psíquicas, influenciam diretamente no reconhecimento. Sobre a rapidez, afirma o autor que o tempo de contato entre o reconhecedor e a pessoa a ser reconhecida influencia no resultado do reconhecimento. Sobre as condições de luz, ensina Altavilla que: diferente é a percepção de uma pessoa durante o dia e durante a noite, em uma zona de luz difusa ou investida por fonte de luz. A respeito da distância, quanto mais próximo mais evidências se notam sobre a pessoa, a distância atenua todas as notas de diferenciação. Quanto à posição da pessoa, uma testemunha que se encontra em posição horizontal (por ex., caso de agressão de uma pessoa) pode com facilidade se equivocar, porque os agressores são vistos de forma diferente, especialmente se as condições de luz não são perfeitas. Sobre as condições psicológicas, arremata o autor afirmando que a emoção influi enormemente no reconhecimento. ${ }^{141}$

Importante, nesse contexto, atentar para o fato de que a condição psicológica do reconhecedor muito influencia no ato de reconhecimento e isso se deve à estreita relação entre memória e emoção e assim, “o medo, a falta de atenção, a ansiedade, a dor etc., são capazes de tornar o reconhecimento um ato não confiável”. ${ }^{142}$

\footnotetext{
${ }^{140}$ Ibidem, p. 500.

${ }^{141}$ ALTAVILLA, Enrico. Psicologia giudiziaria...,p. 336/338. Apud LOPES, Mariângela Tomé. Op. cit. p. 52/53.

${ }^{142}$ TRIGGIANI, Nicola. Ricognizionimezzodi prova nelnuovo processo penale. Milão: Editora Giuffrè, 1998, p. 268 apud LOPES, Mariângela Tomé. Op. cit. p. 108.
} 
Sendo assim, pode-se afirmar que o reconhecimento é um dos meios de prova mais falhos existentes no sistema probatório, uma vez que, além das numerosas causas de distorção e engano a que qualquer processo mnemônico está sujeito, o reconhecimento de pessoas conhece ainda uma considerável série de perturbações que a tornam uma das falíveis formas de aquisição probatória. ${ }^{143}$

Diante disso, a confiabilidade de um reconhecimento deve ser mínima, ressaltando Alessandro Bernasconi que a moderna psicologia confirma os resultados das pesquisas: os percentuais de reconhecimento corretos continuam a se revelar extremamente baixos. ${ }^{144}$

Além de tudo que fora exposto acerca dos aspectos capazes de influenciar negativamente $\mathrm{o}$ ato de reconhecimento, há ainda que se tratar do chamado risco do efeito "yes" tratado por Triggiani.

A respeito desse efeito, o autor esclarece que pesquisas demonstram que o reconhecedor é influenciado a reconhecer uma das pessoas que the são apresentadas, uma vez que há uma grande pressão psicológica sofrida, que faz com que o reconhecedor se sinta na obrigação de reconhecer uma das pessoas, para não decepcionar a autoridade judiciária e por temer as consequências caso não identifique nenhuma daquelas pessoas. ${ }^{145}$

Acerca dessa pressão sofrida pelo reconhecedor, Aury Lopes Jr. bem salienta que essa pode ser policial ou judicial e até mesmo inconsciente da própria pessoa a realizar o ato:

Elementar que a confiabilidade do reconhecimento também deve considerar a pressão policial ou judicial (até mesmo manipulação) e a inconsciente necessidade das pessoas de corresponder à expectativa criada, principalmente quando o nível sociocultural da vítima ou testemunha não lhe dá suficiente

\footnotetext{
143 SEIÇA, Alberto Medina de. Legalidade e reconhecimentos 'atípicos'...p. 1415/1416 apud LOPES, Mariângela Tomé. Op. cit. p. 110

${ }^{144}$ BERNASCONI,Alessandro. La ricognizionedipersone... p. 21 apud LOPES, Mariângela Tomé. Op. cit. p. 108.

${ }_{145}$ TRIGGIANI, Nicola. Ricognizionimezzodi prova nelnuovo processo penale. Milão: Editora Giuffrè, 1998.p. 274 apud LOPES, Mariângela Tomé. Op. cit. p. 110.
} 
autonomia psíquica para descolar-se do desejo inconsciente de atender (ou de não frustrar o pedido da "autoridade"). ${ }^{146}$

Por tal razão, resta incontroverso que o reconhecimento não pode ser o único elemento para fundamentar o juízo de certeza quanto à autoria delitiva, uma vez que consiste em um meio de prova extremamente frágil e falho.

Esclarecido isso, importante se faz atentarmos para outras especificidades que influenciam significativamente no ato de reconhecimento. São essas a seletividade penal e o fenômeno denominado cross-race effect.

\subsection{Seletividade Penal}

Nesse contexto da fragilidade do ato de reconhecimento, importante tratar da seletividade penal, uma vez que vivemos em uma realidade social na qual o racismo constitui uma regra orientadora do sistema jurídico-penal, o que faz com que as vítimas e testemunhas tendam a ver e ouvir aquilo que querem, esperando atender às expectativas da sociedade.

Para tratar disso, no entanto, é necessário compreender, mesmo que de forma breve e sucinta, como o processo de criminalização se desenvolve.

A criminalização primária, conforme preceitua Zaffaroni, é “o ato e o efeito de sancionar uma lei penal material que incrimina ou permite a punição de certas pessoas". Trata-se de uma criminalização no âmbito legislativo, na tipificação das condutas. Já a criminalização secundária "é a ação punitiva exercida sobre pessoas concretas", realizando-se na medida em que a lei passa a ser aplicada. ${ }^{147}$

\footnotetext{
${ }^{146}$ LOPES JR., Aury. Direito Processual Penal. São Paulo: Saraiva, 2015. p. 502.

${ }^{147}$ ZAFFARONI, E. Raúl; BATISTA, Nilo; ALAGIA, Alejandro e SLOKAR, Alejandro. Dirieto penal brasileiro: teoria geral do direito penal v.1. Rio de Janeiro: Ed. Revan, 2003, p. 43.
} 
Desse modo, entende-se por sistema penal "o conjunto das agências que operam a criminalização (primária e secundária) ou que convergem na sua produção" ${ }^{148}$. Tratando-se, portanto, da engrenagem formada pelo Poder Legislativo, Judiciário, Ministério Público, Polícia, Sistema carcerário e demais agências - como as de comunicação social, já que as mídias de massa exercem um papel decisivo no processo de construção das noções de delito e de criminoso na atualidade - formais de controle, que orientam suas ações para a retirada do convívio social dos membros considerados 'fora do lugar'. ${ }^{149}$

Nesse sentido, João Ricardo Dornelles caracteriza o controle social como o conjunto de meios utilizados pela sociedade para lidar com indivíduos ou grupos que ameaçam a ordem estabelecida. Em relação àqueles classificados como desviados, transgressores, delinquentes $\mathrm{e}$ indesejáveis são mobilizados mecanismos públicos e privados de controle social que objetivam adestrar, excluir, segregar, vigiar, punir, aniquilar. ${ }^{150}$

Sendo assim, tanto na enunciação dos tipos penais, quanto na sua aplicação, "cabe às instituições públicas de criminalização primária e secundária a tarefa de segregar os inadaptados. Parte-se do pressuposto de que a contenção exercida pelos órgãos que compõem o sistema penal tem cunho eminentemente racial". ${ }^{151}$

Em outras palavras, o nosso sistema jurídico penal - desde a abordagem policial, passando pelo ato de reconhecimento do suspeito, encarando toda instrução probatória, até chegar ao momento de ser proferida a sentença - é orientado por um racismo estrutural.

\footnotetext{
${ }^{148}$ ZAFFARONI, E. Raúl; BATISTA, Nilo; ALAGIA, Alejandro e SLOKAR, Alejandro. Dirieto penal brasileiro: teoria geral do direito penal v.1. Rio de Janeiro: Ed. Revan, 2003p. 60.

149 PIRES, Thula Rafaela de Oliveira. Criminalização do racismo: entre política de reconhecimento e meio de legitimação do controle dos não reconhecidos. Rio de Janeiro. 2003. Tese de doutorado em Direito da PUC-Rio, p. 247.

${ }^{150}$ João Ricardo Dorneles (2008:20) apud PIRES, Thula Rafaela de Oliveira. Op. cit. p. 247.

${ }^{151}$ PIRES, Thula Rafaela de Oliveira. Op. cit. p. 248.
} 
Acerca da seletividade do sistema penal e o ilusório discurso de que a lei é para todos, Focault esclarece:

Seria hipocrisia ou ingenuidade acreditar que a lei é feita para todo mundo em nome de todo mundo; que é mais prudente reconhecer que ela é feita para alguns e se aplica a outros; que em princípio ela obriga a todos os cidadãos, mas se dirige principalmente às classes mais numerosas e menos esclarecidas; que, ao contrário do que acontece com as leis políticas ou civis, sua aplicação não se refere a todos da mesma forma; que nos tribunais não é a sociedade inteira que julga um de seus membros, mas uma categoria social encarregada da ordem sanciona outra fadada à desordem. ${ }^{152}$

Dito isso, vale considerar o levantamento nacional de informações penitenciárias - INFOPEN, divulgado em dezembro de 2017, acerca de dados colhidos em 2016. ${ }^{153}$

De acordo com o levantamento, em junho de 2016, a população carcerária brasileira contava com 726.712 presos, levando o Brasil a assumir o terceiro lugar no ranking de países que mais prendem no mundo, sendo o público alvo desse sistema prisional bem definido.

Trata-se de jovens negros de baixa escolaridade, acusados de tráfico e crimes patrimoniais. Os dados revelam que 55\% dos presos têm até 29 anos, mas considerando até 34 anos, a fração se eleva para 74\%. No total, $64 \%$ dos presos são negros e se considerarmos apenas a população do sistema penitenciário federal, sobe para $73 \%$.

Desse modo, ainda que as ideias de Lombroso acerca do criminoso nato - baseadas nas características sociais e culturais para identificar biologicamente os autores de crimes - tenham sido superadas, sendo apenas um marco histórico da criminologia, resta evidente que "ele habita o imaginário de muitos (principalmente em países com profundos contrastes

\footnotetext{
${ }^{152}$ FOUCALT, Michel. Vigiar e punir: nascimento da prisão. Tradução de Raquel Ramalhete. $34^{\mathrm{a}}$ ed. Petrópolis, RJ: Vozes, 2007. p. 229.

153 SANTOS, Thandara; ROSA, Marlene Inês da; INFOPEN. Levantamento nacional de informações penitenciárias. 2017.Disponível em: <http://depen.gov.br/DEPEN/noticias1/noticias/infopen-levantamento-nacional-de-informacoes-penitenciarias-

2016/relatorio_2016_22111.pdf> Acesso em: 30 de maio de 2019.
} 
sociais, baixo nível cultural e, por consequência, alto índice de violência urbana como o nosso)". ${ }^{154}$

Esclarecido isso, os dados apresentados só evidenciam e reforçam o que vem sendo aqui explanado: os estereótipos culturais - como cor e classe social - têm sim uma grande influência na percepção dos delitos.

Por conta dessa influência, pode-se dizer que vítimas e testemunhas têm uma tendência de reconhecer em função desses estereótipos e um exemplo típico é o que ocorre nos crimes patrimoniais com violência, o roubo, em que a raça e perfil socioeconômico são estruturantes de um verdadeiro estigma. ${ }^{155}$

Nesse sentido, Giuliana Mazzoni enfatiza que:

Um estereótipo é uma forma de conhecimento, ou melhor, de convicção, estruturada de forma rígida e, portanto, dificilmente modificável, mesmo que sejam apresentadas informações contrárias a ela. (...) Quando há um delito costuma-se deduzir que o infrator seja negro. Suponhamos que uma pessoa branca presencie um assalto e vislumbre o culpado. Se ela compartilhar do preconceito, este será ativado de modo quase automático na memória: no momento em que assistir à cena ou quando tentar recordá-la. O conteúdo do preconceito contaminará assim a lembrança que se tem do ladrão. (...) A recordação de um negro no papel de ladrão não é sinal de má-fé ou de confusão mental, mas produto da ativação inconsciente de informações prévias. ${ }^{156}$

Dito isso, tem-se que, além de todos os fatores previamente esclarecidos acerca da fragilidade do ato de reconhecimento, as expectativas criadas no reconhecedor - mesmo que inconscientemente também influenciam nesse meio de prova.

Sendo assim, a seletividade penal do nosso sistema de justiça é mais um dentre os diversos fatores e moduladores que influenciam no ato de reconhecimento, fazendo com que essa prova, por si só, não seja confiável a ponto de lastrear sentenças condenatórias, como muito já fez e faz.

\footnotetext{
${ }_{155}^{154}$ LOPES JR., Aury. Direito Processual Penal. São Paulo: Saraiva, 2015. p. 501.

${ }^{155} \mathrm{Idem}$

${ }^{156}$ MAZZONI, Giuliana. Crimes, testemunhos e falsas recordações. Revista Viver Mente \& Cérebro, São Paulo, ano 1, n. 149, jun. 2005, p. 81.
} 
Desse modo, explanada influência dos estereótipos no ato de reconhecimento, há que se falar de um fenômeno que está ligado a isso, o cross-race effect.

\subsection{Cross-race effect ${ }^{157}$}

Explanada a influência dos estereótipos no ato de reconhecimento, importante se faz tratar do fenômeno conhecido como "cross-race effect", sendo este a tendência que nós seres humanos temos de mais facilmente reconhecer rostos da raça que nos é mais familiar - o que, normalmente, é a própria.

Esse fenômeno é uma das mais consistentes descobertas das pesquisas acerca da percepção facial e tem constantemente sido percebida a sua contribuição significativa para os erros de reconhecimento facial.

Acerca disso, em uma meta-análise de 39 artigos sobre cross-race effect realizada por Meissner e Brigham (2001) concluiu-se que as chances de erro na identificação são 1.56 vezes maiores para pessoas de outras raças do que para pessoas de mesma raça. (...) Então, um negro inocente e suspeito tem $56 \%$ mais chances de ser confundidamente identificado no ato de reconhecimento por uma vítima/testemunha branca do que por uma negra. ${ }^{158}$ (tradução livre)

As causas básicas para a formação desse fenômeno são duas: a falta de experiência e o pensamento categorizado. Merecendo essas causas uma análise mais detida.

No que tange à falta de experiência, argumenta-se, inicialmente, que o cross-race effect começa a partir do fator segregação racial, uma vez que até mesmo sociedades multiculturais como os Estados Unidos da América e

\footnotetext{
${ }^{157}$ A primeira pesquisa a respeito desse tema foi publicada em 1914: Feingold, CA (1914). "The influence of environment on identification of persons and things".Journal of Criminal Law and Police Science.

${ }^{158}$ WELLS, Gary L.; OLSON, Elizabeth A. The other-race effect in eyewitness identification: what do we do about it? In: Psychology Public Policy and Law, 2001.p. 231.
} 
o Reino Unido têm sustentado padrões de segregação racial. ${ }^{159}$ (tradução livre)

Decorrente dessa segregação, a maioria das pessoas tem mais contato substancial com aquelas da mesma raça, em detrimento das pessoas de raças diferentes. ${ }^{160}$ (tradução livre)

Essa diferença de contato é apontada como a causa que leva à experiência diferenciada para processar as diferenças de pessoas da mesma raça ou não - isto é, as pessoas têm mais facilidade em reconhecer pessoas da mesma raça do que de raças distintas -, e é essa experiência que faz crescer a precisão dos reconhecimentos de pessoas da mesma raça.

Diante disso, alega-se que a estratégia mais efetiva na redução dos erros de identificação de pessoas de raças distintas seria a experiência somada à motivação. ${ }^{161}$ As pesquisas evidenciam que, na maioria dos casos, há a experiência necessária para reconhecer rostos de pessoas de diferentes raças, mas se há o desenvolvimento desses recursos efetivamente é a questão relevante. ${ }^{162}$ (tradução livre)

Isso porque, uma categorização social leva à falha desses recursos em muitos casos, razão pela qual se faz necessário esclarecer a segunda causa de formação desse fenômeno.

Com relação ao pensamento categorizado, insta ressaltar que as pessoas recorrem às categorias quando pensam em outras pessoas e essa

\footnotetext{
${ }^{159}$ GOLDSMITH, W. W.; BLAKELY, E. J. (2010). Separate societies: Poverty and inequality in U.S. Cities. Philadelphia: Temple. ApudWILSON, John Paul; HUGENBERG, Kurt; BERNSTEIN, Michael J. The Cross-Race Effect and Eyewitness Identification: How to Improve Recognition and Reduce Decision Errors in Eyewitness Situations. In:Social Issues and Policy Review, 2013, p. 87

${ }^{160}$ MACLIN, O. H; MACLIN, K. M; MALPASS, R.S. (2001) Race, arousal, attention, exposure, and delay: An examination of factors moderating face recognition. Psychology, Public Policy, and Law, 7, p.134-152.

${ }^{161}$ YOUNG, S. G.; HUGENBERG, K. (2012). Individuation motivation and face experience can operate jointly to produce the Own Race Bias. Social Psychological and Personality Science, 3, 80-87 Apud WILSON, John Paul; HUGENBERG, Kurt; BERNSTEIN, Michael J. The Cross-Race Effect and Eyewitness Identification: How to Improve Recognition and Reduce Decision Errors in Eyewitness Situations. In: Social Issues and Policy Review, 2013, p. 90

${ }^{162}$ WILSON, John Paul; HUGENBERG, Kurt; BERNSTEIN, Michael J. The Cross-Race Effect and Eyewitness Identification: How to Improve Recognition and Reduce Decision Errors in Eyewitness Situations. In: Social Issues and Policy Review, 2013, p. 90.
} 
tendência de pensar categoricamente sobre os outros é automática, difundida e ocorre espontaneamente na maioria dos contextos. ${ }^{163}$ (tradução livre)

Por conta disso, quando nos deparamos com alguém, de modo rápido e eficiente, realizamos uma categorização de acordo com as características que sobressaem, tais como idade, sexo, raça. E embora haja exceções, esse pensamento categórico é inevitavelmente ativado quando identificando rostos, especialmente em contextos em que a memória facial seja relevante. ${ }^{164}$ (tradução livre)

Esse processo de encaixar as pessoas nas "caixas" ocorre tão naturalmente que muitas das vezes sequer percebemos o seu desenvolvimento e então, apenas quando somos motivados a pensar cuidadosamente sobre os outros que tendemos a passar pelas categorias, na busca por informações individualizadas. ${ }^{165}$ (tradução livre)

O efeito dessa categorização, contudo, é fazer com que rostos pertencentes à mesma categoria pareçam se misturar e em vez de vistas como indivíduos, as pessoas passam a ser vistas como membros de uma categoria. E quanto mais fortemente essa categoria for ativada, mais fraco se torna um reconhecimento. ${ }^{166}$ (tradução livre)

Desse modo, esse fenômeno sugere que em situações nas quais a raça é relevante, suspeitos podem ser meramente enquadrados de acordo com a raça e, consequentemente, não reconhecidos de fato.

Dito isso, importante atentar que cada uma das causas apresentadas, por si só, já é suficiente para desencadear o fenômeno do cross-race effect $\mathrm{e}$

\footnotetext{
${ }^{163}$ MACRAE, C. N.; BODENHAUSEN, G. V. (2000) Social cognition: Thinking categorically about others. Annual Review of Psychology, 51, 93-120.

${ }^{164}$ WILSON, John Paul; HUGENBERG, Kurt; BERNSTEIN, Michael J. The Cross-Race Effect and Eyewitness Identification: How to Improve Recognition and Reduce Decision Errors in Eyewitness Situations. In: Social Issues and Policy Review, 2013, p. 90.

${ }^{165}$ Brewer, M. B. (1988). A dual process model of impression formation. In T. K. Srull\& R. S. Wyer (Eds.) apud WILSON, John Paul; HUGENBERG, Kurt; BERNSTEIN, Michael J. The Cross-Race Effect and Eyewitness Identification: How to Improve Recognition and Reduce Decision Errors in Eyewitness Situations. In: Social Issues and Policy Review, 2013. p. 90

${ }^{166}$ WILSON, John Paul; HUGENBERG, Kurt; BERNSTEIN, Michael J. Op. cit.
} 
o consequente déficit na memória de uma testemunha ocular, mas juntas elas podem verdadeiramente debilitar a memória.

Sendo assim, pode ser dito que ambas as causas levam a vítima/testemunha a não focar na individualidade do autor da prática delitiva, quando deveria estar assimilando detalhadamente o seu rosto e sua identidade.

Isso ocorre pela falta de habilidade decorrente da fraca experiência ou pela falta de atenção decorrente da categorização, de modo que a vítima/testemunha não foca no que faz o rosto do autor da prática delitiva único e diferente dos demais.

Explanado mais detidamente o cross-race effect, indaga-se: como deve o sistema de justiça lidar com esse fenômeno?

Esse fenômeno é certamente diferente dos demais fatores capazes de influenciar no ato de reconhecimento que foram abordados ao longo desse trabalho. E isso se deve ao fato de a raça ser uma variável do avaliador e não do sistema. ${ }^{167}$ (tradução livre)

Em outras palavras, o sistema de justiça pode controlar o modo como vai selecionar os participantes para o ato de reconhecimento, por exemplo, mas, em contraposição, não pode controlar se a testemunha/vítima e o suspeito serão da mesma raça.

Sendo assim, o guia nacional acerca da evidência do testemunho ocular desenvolvido pelo Departamento de Justiça dos Estados Unidos ("Technical Working Group for Eyewitness Evidence", 1999) não lidou com o fenômeno do cross-raceeffect. Ou seja, preocupou-se com a forma

\footnotetext{
${ }^{167}$ WELLS, G. L. (1978). Applied eyewitness testimony research: System variables and estimator variables. Journal of Personality and Social Psychology, 36, 1546-1557.apud WELLS, Gary L.; OLSON, Elizabeth A. The other-race effect in eyewitness identification: what do we do about it? In: Psychology Public Policy and Law, 2001.p. 239.
} 
do procedimento e não com a avaliação da testemunha/vítima. ${ }^{168}$ (tradução livre)

Isso, contudo, não significa que nada possa ser feito sobre a influência do cross-race effect nos atos de reconhecimento. Apesar de se tratar de uma variável do avaliador, o sistema pode adotar medidas que reduzam os erros provenientes do ato de reconhecimento, sejam eles provenientes do fenômeno das falsas memórias, da seletividade penal ou cross-race effect.

Isto é, não há como tornar esse meio de prova isento de falibilidade, mas a partir da observância das formalidades e da adoção de medidas que serão explanadas adiante, é possível falar em redução dos erros e vícios que levam às condenações injustas.

Importante, nesse contexto, tratar da condenação de inocentes por conta de atos de reconhecimento que identificaram o suspeito errado.

\subsection{The innocence project}

Em decorrência da grande possibilidade de erros ou falhas no reconhecimento, foi criada em 1992, nos Estados Unidos da América, a “The Innocence Project", tendo surgido, apenas em 2016, o Innocence Project Brasil.

Trata-se de uma organização sem fins lucrativos especializada em enfrentar a grave questão de condenações de inocentes, que, além de pedir indenização ao Estado para essas pessoas condenadas injustamente, provoca um debate sobre as causas desse fenômeno e propõe soluções para a prevenção da ocorrência de futuras injustiças.

\footnotetext{
${ }^{168}$ WELLS, G. L. (1978). Applied eyewitness testimony research: System variables and estimator variables. Journal of Personality and Social Psychology, 36, 1546-1557.apudWELLS, Gary L.; OLSON, Elizabeth A. The other-race effect in eyewitness identification: what do we do about it? In: Psychology Public Policy and Law, 2001.p. 239.
} 
A organização, nos EUA, atua com uma política de reforma, na qual o departamento político do The Innocence Project trabalha diretamente com o Congresso, com legisladores estaduais e líderes locais para aprovar leis e políticas que previnam reconhecimentos errados e facilitem que os assistidos pela organização recebam justiça. (tradução livre).

Assim sendo, a organização acredita que melhorar o sistema como um todo é um benefício para toda a sociedade. Isso porque, prisões e condenações de inocentes são evitadas, a polícia e a promotoria têm melhores instrumentos para alcançar os verdadeiros transgressores da lei, as vítimas recebem justiça e a sociedade passa a confiar mais no sistema. (tradução livre).

Nesse contexto, foi feito um levantamento nos EUA, no qual se constatou que aproximadamente $71 \%$ das mais de 360 condenações erradas do país revertidas posteriormente com o advento do exame de DNA foram oriundas de erros cometidos ao identificar os suspeitos no ato do reconhecimento.

A esse respeito, é esclarecido que:

Imprecisos reconhecimentos podem confundir investigações desde os seus primórdios. Um tempo crítico é perdido enquanto a polícia está distraída focada na construção de um caso contra uma pessoa inocente, em vez do real criminoso; e apesar da sólida e crescente prova da imprecisão do tradicional ato de reconhecimento - e a disponibilidade de simples medidas para reformá-lo -, este continua entre as mais comumente usadas e convincentes evidências trazidas contra os réus. ${ }^{169}$ (tradução livre).

Diante disso, a ONG lista as práticas normalmente realizadas no ato de reconhecimento e os problemas provenientes destas, merecendo destaque algumas:

No alinhamento dos suspeitos para a realização do ato de reconhecimento, quem gerencia esse alinhamento, tipicamente, sabe quem é o suspeito da prática delitiva. Pesquisas mostram que esse gerenciador - frequentemente e

\footnotetext{
${ }^{169}$ Eyewitness Identification Reform: Mistaken Identifications are the Leading Factor in Wrongful Convictions, INNOCENCE PROJECT. Disponível $<$ https://www.innocenceproject.org/eyewitness-identification-reform/> Acesso em 07/05/2019.
} 
despropositadamente - dá sinais para a testemunha ocular acerca da pessoa a ser identificada no ato;

No alinhamento dos suspeitos para a realização do ato de reconhecimento, sem instruções de quem gerencia o ato, a testemunha ocular, frequentemente, assume que o autor do crime perpetrado está presente no alinhamento. Isso, geralmente, leva à escolha de uma pessoa sem que haja o levantamento de dúvidas;

Ao alinhar os suspeitos para a realização do ato de reconhecimento, quem gerencia a disposição das pessoas ou das fotos a serem reconhecidas pode escolher compor com não-suspeitos cujas características não correspondam à descrição do suspeito do crime feita pela testemunha, ou ainda, que não se pareçam com o suspeito. Isso pode fazer com que o suspeito se sobressaia para a testemunha, por causa da composição do alinhamento. Essa sugestão desproposital pode levar a testemunha ocular a identificar um indivíduo em particular dentre os outros das fotos ou do alinhamento. ${ }^{170}$ (tradução livre)

Diante dos diversos problemas provenientes do ato de reconhecimento listados pela ONG nos EUA, podemos, comparativamente, analisar o reconhecimento como é (ou deveria ser) realizado no Brasil.

Primeiramente, acerca do conhecimento prévio de quem é o suspeito pela pessoa que gerencia o alinhamento para o ato do reconhecimento, há que se falar que ao ser realizado em sede policial, normalmente, os policiais que organizam e conduzem o ato sabem quem é o suspeito da conduta delitiva.

Já no que tange à possibilidade de o suspeito pela prática delitiva não ter sido colocado no enfileiramento, ocorre que, no Brasil, há a praxe de somente se realizar o ato quando "capturado" um suspeito, não havendo, normalmente, ato de reconhecimento sem o suspeito.

Isto é, diferentemente do que ocorre em diversos estados norteamericanos, no Brasil não é dada, expressamente, ao indivíduo que vai realizar o reconhecimento, a alternativa de não escolher ninguém.

Com relação à disposição de pessoas que não tenham as características fornecidas pela pessoa a realizar o reconhecimento ou até mesmo pessoas que não tenham semelhanças - como, por exemplo, altura $\mathrm{e}$ porte físico que destoa, cor do cabelo ou, até mesmo, cor de pele diferente

${ }^{170}$ Idem. 
da descrita - faz, evidentemente, que a única pessoa que tenha as características descritas se sobressaia dentre as outras e seja reconhecida, se tratando de uma clara inobservância ao que dispõe o Código de Processo Penal.

Em outras palavras, a disposição do suspeito ao lado de outras pessoas de características semelhantes força o reconhecedor a usar a sua memória acerca das características e particularidades do suspeito e não a característica que difere - como, por exemplo, a raça ou o porte físico como forma de identificação.

Assim sendo, em decorrência dos problemas elencados que foram constatados pela ONG nos EUA, foram propostas reformas para melhorar a exatidão do ato de reconhecimento, sendo essas reconhecidas pela polícia, pelo órgão acusador e pelo Poder Judiciário, assim como pelas organizações nacionais de justiça, incluindo o Instituto Nacional de Justiça (National Institute of Justice) e a Ordem dos Advogados norte-americana (American Bar Association), tendo os benefícios das reformas sido corroborados por mais de trinta anos de pesquisa científica especializada. ${ }^{171}$ (tradução livre)

Dentre as medidas trazidas com a reforma para melhorar o ato de reconhecimento, evitando assim, mais injustiças, importante se faz listar algumas delas:

- O procedimento da dupla cegueira: neste alinhamento, nem quem gerencia o reconhecimento e nem a testemunha ocular sabem quem é o suspeito da prática delitiva. Isso previne que o gerenciador do ato de reconhecimento dê involuntários e despropositados, verbais ou não, sinais que podem influenciar na identificação do suspeito;

- Instruções: trata-se de uma série de declarações feitas por quem gerencia o ato de reconhecimento para o indivíduo que vai realizá-lo, de modo que ele não se sinta compelido a escolher alguém. Isso também previne a testemunha ocular de olhar para quem gerencia o reconhecimento durante o ato na espera de um retorno acerca da identificação. Uma das instruções recomendadas é no sentido de advertir o reconhecedor de que o suspeito pode ou não estar presente dentre aqueles alinhados;

- Composição do alinhamento: a fotografia do suspeito utilizada deve ser selecionada de modo que não se chame atenção não razoável para ele. E as fotos

${ }^{171}$ Disponível em: <https://www.innocenceproject.org/eyewitness-identification-reform/> Acesso em 07/05/2019. 
dos não-suspeitos ou as pessoas que se enfileirarão junto do suspeito devem ser escolhidas, de modo que o suspeito não se sobressaia dentre as características dos demais. O cumprimento da lei deveria selecionar os não-suspeitos usando uma abordagem combinada que considere as características semelhantes à descrição fornecida pela testemunha ocular e sua semelhança com o suspeito que a polícia encontrou;

- Declaração de confiança: Imediatamente após o ato de reconhecimento, a testemunha ocular deve fazer uma declaração, em suas próprias palavras, que articule o nível de confiança/certeza que teve na identificação feita;

- O procedimento deve ser documentado: Idealmente, o ato de reconhecimento deveria ser eletronicamente registrado. Se isso for impraticável, um áudio ou registro escrito deve ser feito. ${ }^{172}$ (tradução livre)

Ao observar estas medidas, resta evidente que - apesar da falibilidade do reconhecimento visual e da fragilidade desta prova - existem meios de reduzir as identificações erradas no ato do reconhecimento.

Com efeito, nunca haverá um modo de garantir que o reconhecimento seja totalmente confiável e certo, mas observando essas medidas, as chances de enganos são, de fato, reduzidas.

Importante destacar que as medidas trazidas pela ONG juntamente ao governo norte-americano foram implementadas em 24 estados norteamericanos e integram atualmente o protocolo do departamento de justiça dos EUA, sendo um grande passo na redução de reconhecimento de inocentes erradamente.

Em suma, é extremamente importante que quem conduza o ato de reconhecimento não saiba previamente quem é o suspeito; que a testemunha ocular saiba que não necessariamente o autor do fato estará dentre as pessoas a serem alinhadas para o reconhecimento; que não é obrigatório escolher alguém, sendo possível alegar que não se está confiante o bastante para apontar o culpado; que as pessoas que serão reconhecidas sejam efetivamente parecidas com a descrição da testemunha ocular e umas com as outras; dentre outras medidas.

\footnotetext{
${ }^{172}$ Disponível em: <https://www.innocenceproject.org/eyewitness-identification-reform/> Acesso em 07/05/2019.
} 


\subsection{A necessidade de redução de danos}

Além das medidas propostas e implementadas nos Estados Unidos da América, que poderiam ser aplicadas ao ato de reconhecimento realizado no Brasil também, uma vez que reduzem os erros do ato, outras reformas merecem ser analisadas.

Inicialmente, insta ressaltar que antes mesmo de se falar em qualquer reforma no modo como o ato é conduzido, é preciso que: 1 . Seja observada a forma prevista no Código de Processo Penal, pois não adianta falar em reformar normas que já não são cumpridas; 2 . Se compreenda que ainda que sejam implementadas medidas capazes de melhorar a qualidade do ato de reconhecimento, fato é que este nunca será um meio de prova livre da fragilidade que o perpassa pelas falhas da memória e pelos outros fatores já analisados.

Sendo assim, pode-se dizer que o método aqui abordado e escolhido pelo nosso ordenamento jurídico de realização do ato de reconhecimento consiste no reconhecimento simultâneo, no qual todas as pessoas são mostradas ao mesmo tempo, para a identificação pelo reconhecedor.

Por ser esse método sugestivo e perigoso, há quem sugira a substituição do reconhecimento simultâneo pelo sequencial - modelo em que os suspeitos são apresentados um de cada vez -, já que este seria mais seguro e confiável.

Acerca do reconhecimento sequencial, Anna Virginia Williams, ao citar Lindsay e Wells, explicou que nesse método de reconhecimento "os suspeitos são apresentados um de cada vez e, para cada um, é solicitado à testemunha ou vítima que, antes de ver o próximo suspeito, responda se foi esse o autor do fato ou não". ${ }^{173}$

\footnotetext{
173 WILliAMS, Anna Virginia. Implicações Psicológicas no Reconhecimento de Suspeitos: avaliando o efeito da emoção na memória de testemunhas oculares. Trabalho de Conclusão de Curso (Graduação em Psicologia) - Pontifícia Universidade Católica do Rio Grande do Sul. Orientador: Celito Francisco Mengarda, 2003. Apud LOPES JR., Aury. Direito Processual Penal. São Paulo: Saraiva, 2015. p. 503.
} 
Desse modo, é exigido do reconhecedor que uma decisão seja tomada, sem saber quantos ainda restam para o reconhecimento e também como eles serão, sendo reduzido o nível de indução e potencializada a qualidade do ato.

Isso porque, se no reconhecimento simultâneo o pessoa a realizar o ato de reconhecimento "faz um julgamento relativo no processo de tomada de decisão (Wells, 1984), isto é, ela toma sua decisão julgando qual o membro mais semelhante ao culpado, comparando os membros entre si", no reconhecimento sequencial, "a testemunha faz um julgamento absoluto, comparando cada membro do reconhecimento com a sua própria memória do culpado". 174

Outra medida muito importante e já mencionada anteriormente é a necessidade de esclarecer ao reconhecedor que o suspeito pode não estar entre as pessoas a serem reconhecidas, bem como a de se realizar atos de reconhecimento sem o suspeito presente, pois a pré-compreensão de que somente se realiza o ato com algum suspeito acaba por induzir o reconhecedor e aumentar os índices de erros.

Acerca disso, Cristina Di Gesu ressalta que "muitas identificações são positivadas justamente devido à crença das pessoas de que a polícia somente realiza um reconhecimento quando já tem um bom suspeito". ${ }^{175}$

No mesmo sentido, Giacomolli trata da confiabilidade do reconhecimento atrelada à liberdade de quem vai realizar o reconhecimento:

Há de ser instruído corretamente. O primeiro passo é advertir o reconhecedor que entre os sujeitos que lhes são mostrados, o autor do fato poderá não estar presente. Desta forma, pode ser afastado um juízo relativo, por um lado e, de outra banda, se legitima um eventual não reconhecimento. ${ }^{176}$

\footnotetext{
174 WILLIAMS, Anna Virginia. Implicações Psicológicas no Reconhecimento de Suspeitos: avaliando o efeito da emoção na memória de testemunhas oculares. Trabalho de Conclusão de Curso (Graduação em Psicologia) - Pontifícia Universidade Católica do Rio Grande do Sul. Orientador: Celito Francisco Mengarda, 2003. Apud LOPES JR., Aury. Op. cit. p. 504

${ }^{175}$ DI GESU, Cristina. Op. cit. p. 160.

${ }^{176}$ GIACOMOLLI, Nereu José. A fase preliminar do processo penal: crises, misérias e novas metodologias investigativas, 2011, p. 157-158.
} 
Nesse sentido, Aury Lopes Jr. comenta um experimento realizado por Malpass e Devine, no qual uma simulação foi feita:

Montado o reconhecimento, foi informado aos presentes (aqueles que deveriam proceder à identificação) que o autor do delito estava provavelmente presente (quando na verdade não estava). Setenta e oito por cento dos sujeitos reconheceram erroneamente o agressor. Mas quando avisaram que o autor podia não estar presente, o índice de reconhecimento caiu para 33\%. Definitivamente, a forma como é conduzido e montado o reconhecimento afeta o resultado final, de forma muito relevante. ${ }^{177}$

Diante disso, Aury Lopes Jr. reconhece que a incorporação dessa simples cautela de advertir a testemunha ou vítima de que o suspeito pode ou não estar presente, "reduz a margem de erros de um reconhecimento feito a partir da pré-compreensão (e indução, ainda que endógena) de que o suspeito está presente". ${ }^{178}$

Para além dessas modificações, fala-se também na realização de um teste de confiabilidade do reconhecedor, isto é, a realização de dois atos de reconhecimento, o primeiro apenas com suspeitos distratores- sem a presença do verdadeiro suspeito - e o segundo com o real suspeito participando do ato. Em outras palavras:

Apresentar, primeiramente, um reconhecimento somente com a presença de suspeitos distratores, contudo, não é dito a ela que será apresentado mais de um grupo de suspeitos. Caso a testemunha faça alguma identificação nesse reconhecimento, então ela pode ser descartada, e, caso a testemunha não faça nenhuma identificação no primeiro reconhecimento, então pode ser dada continuidade ao procedimento, apresentando o segundo reconhecimento com a presença do suspeito alvo. Dados indicam que testemunhas que não fazem identificações no primeiro reconhecimento são muito mais confiáveis ${ }^{179}$

Por fim, outra medida também já ventilada e importante para a melhora do ato é que a pessoa que conduza o reconhecimento não faça parte do grupo que realiza a investigação, isto é, quem conduz o ato não deve

\footnotetext{
${ }^{177}$ LOPES JR., Aury. Direito Processual Penal. São Paulo: Saraiva, 2015. p. 503.

${ }^{178}$ LOPES JR., Aury. Direito Processual Penal. São Paulo: Saraiva, 2015. p. 504.

179 WILLIAMS, Anna Virginia. Implicações Psicológicas no Reconhecimento de Suspeitos: avaliando o efeito da emoção na memória de testemunhas oculares. Trabalho de Conclusão de Curso (Graduação em Psicologia) - Pontifícia Universidade Católica do Rio Grande do Sul. Orientador: Celito Francisco Mengarda, 2003. Apud LOPES JR., Aury. Op. cit. p. 504-505
} 
saber, previamente, quem é o suspeito da prática delitiva, evitando assim, qualquer tipo de indução e contaminação do ato.

Dito isso, tem-se que não só através de uma reforma legislativa seria possível melhorar o ato de reconhecimento - reduzindo os danos e, consequentemente, a elevada injustiça das identificações erradas -, mas também por meio da adoção de simples medidas e cuidados ao formato já existente. 


\section{CONCLUSÃO}

Ao longo do presente trabalho, buscou-se esclarecer que o ato de reconhecimento consiste em um meio de prova frágil, falho e pouco confiável, amplamente suscetível a erros e vícios.

Constatou-se, desse modo, que existem diversos fatores capazes de influenciar na qualidade e eficácia do ato de reconhecimento tal como é realizado e a necessidade de buscar uma redução de danos e injustiças, uma vez que esse ato já levou e ainda leva inúmeros inocentes à condenação, quando lastreando uma sentença condenatória sem outras provas aptas a corroborar a autoria delitiva.

Dentre esses fatores, enfatizou-se muito a necessidade de que sejam observadas as formalidades previstas em lei, uma vez que, para o Processo Penal, forma é garantia do cidadão perante o Estado e as suas arbitrariedades, de modo que a atuação do Poder Estatal se deslegitima quando não observa à lei e trata a forma como mera recomendação legal.

Além disso, o ato de reconhecimento consiste em uma prova eminentemente cognitiva e, portanto, suscetível aos sugestionamentos provenientes das falsas memórias, se mostrando esse meio de prova, novamente, como extremamente passível de erros.

Outrossim, analisados a seletividade penal e o cross-race effect, demonstrou-se, de outras formas, que o ato de reconhecimento jamais será uma prova isenta dos erros provenientes da memória e dos estereótipos criados dentro da sociedade, de modo que se fez necessária uma análise acerca de medidas importantes para a redução dos danos decorrentes dessa prova.

Assim sendo, tratou-se do The Innocence Project, uma vez que essa organização, após estudos especializados em conjunto com o aparato estatal dos EUA, reformulou a forma como o ato vinha sendo conduzido em diversos estados norte-americanos. 
Diante disso, enfatizou-se que o presente trabalho jamais buscou descredibilizar esse meio de prova, tampouco objetivou apontar soluções para os problemas decorrentes dessa prova, já que não há que se falar em soluções simples para questões altamente complexas, de tal sorte que se buscou analisar criticamente o ato de reconhecimento, apontando sua inegável fragilidade, falibilidade e pouca confiabilidade, discutindo, ao final, medidas capazes de melhorar sua qualidade.

Isto posto, sendo certo que não há meio de se assegurar a infalibilidade dessa prova, importante é, ao menos, que se busque a redução dos danos e injustiças provenientes dela.

Sendo assim, seja por meio de mudanças na lei - alterando a forma tal como o ato é ou adicionando requisitos para a sua realização às normas vigentes -, bem como a partir da adoção de medidas práticas ao formato atual, é possível falar em redução nos erros.

Desse modo, tratou-se de algumas medidas capazes de melhorar significativamente a qualidade do ato, sendo estas: a condução do ato de reconhecimento por pessoa que não saiba previamente quem é o suspeito a ser reconhecido; que ao reconhecedor seja informado que o autor do fato não necessariamente está entre as pessoas apresentadas para o ato; que não há obrigatoriedade em escolher alguma das pessoas mostradas; bem como que as pessoas se pareçam com as características descritas pela vítima e também umas com as outras.

Merecendo atenção ainda uma possível alteração legislativa, no sentido de se substituir o reconhecimento simultâneo pelo sequencial, para evitar que, em detrimento de um ato no qual o reconhecedor compara as pessoas entre si, passe a haver um em que o reconhecedor exerça um julgamento absoluto, já comparando cada pessoa com a sua própria memória do culpado.

Dito isso, concluiu-se, por fim, diante de tudo que foi exposto ao longo desse trabalho que não se pode condenar um indivíduo cuja autoria 
delitiva esteja amparada somente em um ato de reconhecimento, uma vez que há inúmeras falhas decorrentes desse meio de prova. 


\section{REFERÊNCIAS BIBLIOGRÁFICAS}

BADARÓ, Gustavo Henrique Righi Ivahy. Direito Processual Penal. São Paulo: Campus Jurídico, 2008, Tomo I.

COUTINHO, Jacinto Nelson de Miranda. O papel do novo juiz no processo penal. Crítica à Teoria Geral do Direito Processual Penal. Coord. Jacinto Nelson de Miranda Coutinho. Rio de Janeiro: Renovar, 2001.

COUTINHO, Jacinto Nelson de Miranda. Introdução aos Princípios Gerais do Processo Penal Brasileiro.

DA SILVA JÚNIOR, Walter Nunes. Princípios da presunção de inocência $e$ da não culpabilidade: distinção, aplicação e alcance. In: Revista Constituição e Garantias de Direitos.

DAMÁSIO, Antônio. O Erro de Descartes: emoção, razão e o cérebro humano. Trad. Portuguesa Dora Vicente e Georgina Segurado. São Paulo: Companhia das Letras, 1996.

DE LIMA, Renato Brasileiro. Manual de Processo Penal. Salvador: JusPodivm, 2016.

DE LIMA, Renato Brasileiro. Material Suplementar $1^{\circ}$ semestre 2016. Salvador: JusPodivm, 2016.

DI GESU, Cristina. Prova Penal e Falsas Memórias. Porto Alegre: Livraria do Advogado, 2014.

Eyewitness Identification Reform: Mistaken Identifications are the Leading Factor in Wrongful Convictions, INNOCENCE PROJECT. Disponível em: $\quad<\mathrm{https} / / \mathrm{www}$.innocenceproject.org/eyewitnessidentification-reform/> Acesso em 07/05/2019.

EYSENCK, Michael W.; KEANE, Mark T. LOPES, Magda França.(Trad.). Manual de Psicologia Cognitiva. 5a ed. Porto Alegre: Artmed, 2007.

FERRAJOLI, Luigi. Direito e razão. 2. ed. rev. e ampl. Tradução de Ana Paula Zomer, Fauzi Hassan Choukr, Juarez Tavares e Luiz Flávio Gomes. São Paulo: Ed. RT, 2006.

FERREIRA, Aurélio Buarque de Holanda. Dicionário do Aurélio Online. Disponível em: $<$ https://dicionariodoaurelio.com/reconhecer $>$. Acesso em: 11/05/2019. 
FOUCALT, Michel. Vigiar e punir: nascimento da prisão; tradução de Raquel Ramalhete. 34a ed. Petrópolis, RJ: Vozes, 2007.

GIACOMOLLI, Nereu José. A fase preliminar do processo penal: crises, misérias e novas metodologias investigativas, 2011.

GIACOMOLLI, Nereu José; DI GESU, Cristina Carla. As Falsas Memórias na Reconstrução dos Fatos pelas Testemunhas no Processo Penal.

GIACOMOLLI, Nereu. José. Atividade do Juiz Criminal Frente à Constituição: deveres e limites em face do princípio acusatório. Sistema Penal e Violência. Ruth Maria Chittó Gauer (coord.), 2006.

GIACOMOLLI, Nereu. Juizados Especiais Criminais. Lei 9.099/95. $2^{\mathrm{a}}$ ed., 2002.

GLOECKNER, Ricardo Jacobsen. Nulidades no Processo Penal. 3. ed. São Paulo: Saraiva, 2017.

GOLDSCHMIDT, James. Princípios Gerais do Processo Penal, 2002.

GOMES FILHO, Antonio Magalhães e BADARÓ, Henrique Righi Ivahy. Prova e sucedâneos de prova no processo penal brasileiro. Revista Brasileira de Ciências Criminais, $n^{0}$ 65, São Paulo: Editora Revista dos Tribunais, março-abril 2007.

GRINOVER, Ada Pellegrini; GOMES FILHO, Antonio Magalhães; FERNANDES, Antonio Scarance. As nulidades no processo penal. 7. ed. São Paulo: RT, 2001.

IZQUIERDO, Ivan. Memória. Porto Alegre: Artmed, 2006.

LOFTUS, Elizabeth. As falsas lembranças, in: Viver mente \&cérebro.

LOPES JR., Aury. Direito Processual e a sua Conformidade Constitucional. v. I. $8^{\text {a }}$ ed. Porto Alegre: Lumen Juris, 2011

LOPES JR., Aury. Direito Processual Penal e sua conformidade constitucional. Vol. I, 2007.

LOPES JR., Aury. Direito Processual Penal. São Paulo: Saraiva, 2015.

LOPES JR., Aury. Introdução Crítica ao Processo Penal - Fundamentos da Instrumentalidade Garantista, $3^{\mathrm{a}}$ ed., 2005. 
LOPES JR., Aury; GESU, Cristina Di. Falsas memórias e prova testemunhal no processo penal: em busca da redução de danos. In: Revista de Estudos Criminais, Ano VII, n. 25. Sapucaia do Sul: 2007.

LOPES, Mariângela Tomé. O Reconhecimento como Meio de Prova: Necessidade de reformulação do direito brasileiro. São Paulo: 2011. Tese de Doutorado Faculdade de Direito da Universidade de São Paulo.

MACLIN, O. H; MACLIN, K. M; MALPASS, R.S. Race, arousal, attention, exposure, and delay: Na examination of factors moderanting face recognition. Psychology, Public Policy, and Law, 7, p.134-152, 2001.

MACRAE, C. N.; BODENHAUSEN, G. V. (2000) Social cognition: Thinking categorically about others. AnnualReviewofPsychology.

MAZZONI, Giuliana. Crimes, testemunhos e falsas recordações. Revista Viver Mente \& Cérebro, São Paulo, ano 1, n. 149, jun. 2005.

NEUFELD, Carmen Beatriz et. al. Compreendendo o Fenômeno das Falsas Memórias. In: STEIN, Lilian Milnitsky et. al. Falsas Memórias: Fundamentos Científicos e suas Aplicações Clínicas e Jurídicas. Porto Alegre: Artmed, 2010.

NUCCI, Guilherme de Souza. Provas no Processo Penal. Rio de Janeiro: Forense, 2015.

PACELLI, Eugênio; FISCHER, Douglas. Comentários ao Código de Processo Penal e sua jurisprudência, $4^{\mathrm{a}}$ ed. revista e atualizada, São Paulo, Atlas, 2012.

PIRES, Thula Rafaela de Oliveira. Criminalização do racismo: entre política de reconhecimento e meio de legitimação do controle dos não reconhecidos. Rio de Janeiro. 2003. Tese de doutorado em Direito da PUCRio.

RANGEL, Paulo. Direito Processual Penal. Rio de Janeiro: Lumen Juris, 2009.

SANTOS, Thandara; ROSA, Marlene Inês da; INFOPEN. Levantamento nacional de informações penitenciárias. 2017.Disponível em: $<$ http://depen.gov.br/DEPEN/noticias-1/noticias/infopen-levantamentonacional-de-informacoes-penitenciarias-2016/relatorio_2016_22111.pdf $>$ Acesso em: 30 de maio de 2019.

SCHACTER, Daniel L. Os Sete Pecados da Memória: Como a Mente Esquece e Lembra. Rio de Janeiro: Rocco, 2003. 
STEIN, Lilian Milnilsky e PERGHER, Giovanni Kuckartz. Criando falsas memórias em adultos por meio de palavras associadas, in Psicologia: Reflexão e Crítica.

STEIN, Lilian Milsnitsky et. al. Falsas memórias: fundamentos científicos e suas aplicações clínicas e jurídicas. Porto Alegre: Artes Médicas, 2010.

TÁVORA, Nestor e ALENCAR, Rosmar Rodrigues. Curso de Direito Processual Penal. 4. ed. Salvador: Jus Podivm. 2010.

THOMPSON, Augusto. Quem são os criminosos? 2.ed. Rio de Janeiro: Editora Lumen juris, 2007.

TOURINHO FILHO, Fernando da Costa. Código de Processo Penal Comentado. 13. ed. rev. e atual. São Paulo: Saraiva, 2010.

TOURINHO FILHO, Fernando. Processo Penal. v. I. $35^{\mathrm{a}}$ edição. São Paulo: Saraiva, 2013.

WELLS, Gary L.; OLSON, Elizabeth A. The other-race effect in eyewitness identification: what do we do about it? In: Psychology Public Policy and Law, 2001.

WILSON, John Paul; HUGENBERG, Kurt; BERNSTEIN, Michael J. The Cross-Race Effect and Eyewitness Identification: How to Improve Recognition and Reduce Decision Errors in Eyewitness Situations. In: Social Issuesand Policy Review, 2013.

ZAFFARONI, Eugenio Raúl et al. Direito penal brasileiro. Rio de janeiro: Revan, v. 1, p. 131, 2003. 